\title{
DE SUBDELEGADO A JEFE POLÍTICO: \\ LA CONFORMACIÓN DE LA AUTORIDAD \\ GUBERNATIVA 1812-1841. PLANTEAMIENTO A PARTIR DEL CASO DE YUCATÁN*
}

\author{
Laura Brondino \\ Sorbonne Université
}

\section{INTRODUCCIÓN}

esde hace ya bastantes años, la historiografía latinoameri-
canista ha renovado su lectura de la historia político-ins-
titucional del siglo xix, por largo tiempo considerada el fracaso
de la modernidad política. En particular, la ahora abundante

Fecha de recepción: 25 de septiembre de 2017

Fecha de aceptación: 24 de julio de 2018

\footnotetext{
* La realización de este artículo fue posible gracias a una beca posdoctoral (2016-2017) en el Centro de Investigaciones y Estudios Superiores en Antropología Social, CIESAS, Unidad Peninsular, y forma parte del proyecto de Ciencia Básica de CONACYT 2015, 254813, "Los subdelegados: poderes intermediarios en la Monarquía Hispánica". Agradezco encarecidamente a Sergio Quezada por su apoyo para la realización de esta investigación. Agradezco también las observaciones de Carlos Garriga a una exposición mía sobre el mismo tema en 2016. Por último, mi agradecimiento por los comentarios de Laura Machuca a una versión preliminar de este texto, así como al Seminario de Historia Política dirigido por Fausta Gantús y Alicia Salmerón en el Instituto Mora, en particular por las observaciones de Israel Arroyo, Andrés Lira y Beatriz Rojas.
} 
literatura sobre las independencias en Latinoamérica se aparta de una lectura normativa de la modernidad, para comprender la individualidad (y diversidad) de las formas de concepción y construcción político-institucional y del ejercicio de la autoridad que se abrieron a partir de la crisis imperial. ${ }^{1}$ Con la reconceptualización e historización de diversos objetos -como las constituciones, la ciudadanía, los ayuntamientos- ha ido aclarándose que las continuidades con el pasado no significan una revolución política fallida o la derrota de un proyecto que, todavía, se tiende a pensar como "importado" del viejo continente. Lo que encontramos, en cambio, es que muchas de las nuevas instituciones que concretaron la revolución política fueron construidas transformando las antiguas, generando así "formas de transición" ${ }^{2}$ no teleológicamente orientadas. Por lo tanto, estas formas no deben ser vistas como escalones o etapas previas hacia una modernidad siempre buscada y nunca alcanzada. No son, pues, reflejo de una imperfecta modernidad, sino que constituyen la historia misma de la formación de los estados latinoamericanos, con su profunda originalidad y con todos sus defectos y virtudes, ambos reconocibles hasta hoy en día.

Pese a su interés intrínseco, las modalidades de concepción y elaboración de las transformaciones, y la naturaleza de las nuevas instituciones, siguen siendo un campo poco explorado. En este sentido, la figura del subdelegado de cuño borbónico resulta especialmente interesante, pues a través de sus mutaciones en el marco gaditano y luego republicano, es decir, por medio de su paulatina conversión en jefe político, podemos observar una de las vertientes de los procesos antes referidos.

\footnotetext{
${ }^{1}$ Mencionamos sólo uno de los primeros trabajos colectivos que inauguraron la renovación en este sentido: Annino, Castro Leiva y Guerra, De los imperios.

2 Lempérière, “La historiografía”, p. 49. Más adelante se remitirá al aporte de los historiadores del derecho que han estudiado estas "formas de transición".
} 
En efecto, como nos lo informa la historiografía reciente, los subdelegados y los jefes políticos, habitualmente descritos como déspotas en las fuentes del periodo, ${ }^{3}$ ejercieron más bien como "mediadores del poder", es decir, como intermediarios entre distintos grupos e intereses. Además de otras cosas, ejercían la mediación entre las instancias superiores de gobierno (primero reales y después republicanas) y las instancias locales $y$, también, mediaban entre esas instancias superiores y la población. ${ }^{4}$ Son justamente los mecanismos de la mediación los que aquí nos interesan. Más concretamente, se trata de explorar el tránsito entre la forma en que ejercieron la mediación los subdelegados y la forma en que la ejercieron los jefes políticos de nombramiento gubernamental. Una indagación como ésta, que no se ha realizado plenamente hasta la fecha, puede ayudarnos a comprender cómo se conformó la autoridad gubernamental

${ }^{3}$ Señalar al subdelegado de factura borbónica como antecedente del jefe político de cuño republicano se ha convertido en lugar común casi desde la aparición del segundo. Ambas figuras han sido comparadas a menudo por su tendencia al despotismo, por no decir que han llegado a simbolizar la arbitrariedad de los sistemas de gobierno de los que formaron parte. Una de las imágenes más llamativas de esta asociación la legó en Yucatán el célebre historiador liberal Eligio Ancona en el último tercio del siglo xIX, quien señala al subdelegado como antecedente del jefe político, para después definir al primero por medio de la imagen "sultánica” que décadas atrás formuló Justo Sierra O’Reilly. ANCONA, Historia, p. 30. Es claro que el temor a la continuación del "despotismo" de los subdelegados por los jefes políticos de nombramiento gubernamental fue una denuncia generalizada en México, desde la aparición de estos últimos en las primeras normativas estatales del periodo independiente. Véase, también por ejemplo, Actas del Congreso, p. 35. Véase Delgado Aguilar, "Orígenes". ${ }^{4}$ A fines de los años ochenta, Romana Falcón abrió una nueva perspectiva sobre el jefe político como dispositivo de construcción del Estado-nación; la focalización en la mediación aparece en FALcón, El jefe político, cap. 5, así como en Brondino, "Les pouvoirs intermédiares", cap. 3 (en proceso de publicación por Éditions Hispaniques, París). Respecto a los subdelegados, véase en particular SiLKe, "Mediadores", pp. 41-63, y el "VI Congreso RERSAB. La cultura de la intermediación en el ámbito subdelegacional”, CIEsAs Peninsular Mérida, 23-25 de noviembre de 2016. 
en el siglo XIX mexicano y, por ende, permitirnos comprender la “arbitrariedad” de la que se le acusó constantemente. En este sentido, aquí planteamos que el subdelegado, comisario judicial de nombramiento real, legó al jefe político, comisario ejecutivo de nombramiento gubernamental republicano, ${ }^{5}$ una concepción tradicional del ejercicio de la autoridad que se prolongó, así, hasta bien entrado el “nuevo régimen”. Esta interpretación añade complejidad a las visiones existentes del jefe político como cabeza de lanza de un incipiente aparato burocrático estatal. Al mismo tiempo, no se pretende aquí afirmar que el jefe político sea una pura continuidad del antiguo régimen, representado por el subdelegado. Se trata, pues, de explorar la complejidad concreta y efectiva de las mutaciones en el ejercicio de la autoridad, mismas que suelen escapar del marco conceptual creado por la división tajante entre antiguo y nuevo régimen. En otras palabras, aquí exploraremos el legado de una concepción jurisdiccional del gobierno y sus efectos en la construcción de una nueva forma de ejercicio de la autoridad, conceptos que explicamos a continuación.

Antes de centrarnos en el tránsito de los subdelegados a los jefes políticos, es necesario describir, aunque sea de forma muy esquemática, la naturaleza del ejercicio de la autoridad dentro de la llamada "monarquía corporativa", ${ }^{6}$ propia del antiguo régimen, de la cual formaban parte los subdelegados. Como ya ha mostrado ampliamente la historiografía, la monarquía dentro del antiguo régimen nunca constituyó una forma de gobierno enteramente dependiente de la voluntad individual del rey,

5 Cabe aclarar que, en ambos casos, por tratarse de figuras comisariales, su autoridad les es delegada por las autoridades superiores que los nombran. Lo que los distingue -y que nos interesa aquí- es que el subdelegado es magistrado, mientras que el jefe político tiene autoridad ejecutiva, concepto este último que se discutirá más adelante. Sobre la naturaleza de la delegación y su evolución, véase Hespanha, La gracia, cap. 2 y Mannori y Sordi, Storia, pp. 102-127. 6 Lempérière, Entre Dieu et le Roi, p. 12. 
incluso en sus momentos más “absolutistas”. Diversos autores la han descrito, más bien, como un "archipiélago de repúblicas”, es decir, no como una sola entidad política, sino como una red de cuerpos autónomos que, en su conjunto, constituían la república: un orden plural, establecido de antemano por voluntad divina y ajeno a la voluntad humana. Teóricamente, entonces, como caput reipublicae (cabeza de la república) al rey le incumbía conservar este orden plural y no ejercer sobre él su voluntad personal. 7

Por su estructura, a este sistema le corresponde un "gobierno de la justicia”, ${ }^{8}$ en el sentido de iurisdictio. ${ }^{9}$ Es decir, que la coacción legítima era fruto de un acuerdo judicial entre grupos o individuos horizontalmente situados entre sí. Cada grupo o individuo podía "negociar” su obediencia ante cualquier disposición de la autoridad haciendo valer intereses o derechos previamente adquiridos mediante un procedimiento judicial, la llamada "vía ordinaria". ${ }^{10}$ La superioridad jerárquica del rey consistía en que era el único que no podía ser juzgado por otros, lo cual hacía de él el intérprete último (es decir, no el único) de la armonización entre esos derechos e intereses diversos. Ello también lo dotaba de una justicia superior, la equidad, ${ }^{11}$ la cual le permitía modificar los derechos sin pasar por la "vía ordinaria". A este atajo se le llamó vía "reservada” o "gubernativa”, y permitía obviar la audiencia y el consentimiento de los afectados,

\footnotetext{
7 Véase, en particular, Lempérière, Entre Dieu et le Roi y RoJAs, Cuerpo político.

8 Retomamos aquí la expresión de Garriga, “Gobierno y justicia”, p. 47.

9 Literalmente, que dice el derecho: el que juzga se limita a confirmar lo que corresponde a cada parte según el derecho establecido de antemano, tras una interpretación circunstanciada del caso.

10 Véase, Mannori, “Giustizia e amministrazione”, p. 49.

11 Para algunas puntalizaciones importantes sobre la equidad y su evolución, véase Tau Anzontegui, Casuismo, pp. 529-534; Hespanha, Introduzione, pp. 129-130.
} 
lo que hacía que sus decisiones fueran ejecutorias. ${ }^{12}$ Por ello la "vía gubernativa" ha sido considerada como una fisura en "el Estado jurisdiccional puro". ${ }^{13}$ Y en efecto, durante el periodo "absolutista" no faltó la tendencia a convertirla en autoridad absoluta e incontestable, no sólo multiplicando su uso, sino insistiendo en que la última palabra la tenía el rey, es decir, que él, en cuanto juez superior, era garante de la justicia por esta vía. Pero, como lo señala, entre otros, Carlos Garriga, se trataba de una "potestad extraordinaria", "excepcional”, que "se justificaba precisamente en las exigencias que la mejor conservación de la respublica imponían en ciertas circunstancias" y que, a fin de cuentas, era siempre apelable. ${ }^{14}$ Lo que significa que, hasta la crisis imperial, la vía gubernativa, lejos de cobrar autonomía, se mantuvo "en un lugar marginal del discurso" 15 jurisdiccional, justificándose a través de él y sin ponerlo en duda.

Esta concepción jurisdiccional de la autoridad estuvo muy presente en la construcción de las nuevas entidades nacionales. Su importancia ya ha sido señalada, sobre todo en el contexto de la revolución política de la soberanía popular, y en relación con la representatividad de los ayuntamientos y su capacidad para rendir justicia. Entre otras cosas, se ha mostrado que estos atributos de los ayuntamientos constituyeron un freno

12 Es decir que tenían que ejecutarse. Aunque tanto en el periodo virreinal como en el republicano muchas veces los términos "ejecutorio" y "ejecutivo" eran intercambiables para remitir a la coacción legítima sin mediar contradictorio, usamos aquí el término "ejecutorio" en el sentido de ejecución inmediata, pero sin excluir una posterior audiencia (apelación) y una posible modificación de la disposición (como se comenta a continuación). El término evita la confusión posible con el "poder ejecutivo" republicano que, en principio, ejecuta y toma disposiciones para ello sin posibilidad de apelación puesto que ejecuta las leyes, ahora expresión de la voluntad general.

${ }_{13}$ Retomamos la expresión de Mannori y Sord, Storia, p. 128.

${ }^{14}$ Garriga, "Gobierno”, p. 53 y siguientes. Véanse también Tau AnzoateGUI, La ley y MANnoRI, "Per una 'preistoria' ”, pp. 323-504.

15 Agüero, "Las categorías", p. 55. 
al monopolio de la autoridad por los nuevos poderes públicos que, justamente, eran los encargados de ejercer la nueva soberanía. ${ }^{16} \mathrm{Al}$ mismo tiempo, esos nuevos poderes públicos fueron permeados por la cultura jurisdiccional, según ha sido aclarado recientemente por la historia crítica del derecho. En efecto, la Constitución gaditana no rompió con las formas antiguas de gobierno, al contrario, las "constitucionalizó", esto es, echó mano de los dispositivos institucionales existentes para poner en planta la propia Constitución. ${ }^{17}$ Esta supervivencia significa que se siguió concibiendo la coacción legítima como resultado de un procedimiento de cuño jurisdiccional. Lo anterior minó el surgimiento del nuevo "orden legal" que implicaba la formación de un nuevo tipo de poder, el ejecutivo, cuya coacción legítima se sostiene en la ejecución de la ley, sin dar lugar a ninguna forma de composición o juicio.

Para comprender cabalmente lo anterior, vale la pena recordar, de forma muy esquemática, cómo se conformó el poder ejecutivo en Francia a partir de la Revolución, pues el caso francés ha sido considerado modélico. En nombre de la ejecución de la ley, el inicialmente raquítico poder ejecutivo dio lugar a un sujeto autónomo y ulterior a la propia ley, la llamada Administración Pública, cuya coacción legítima no dependía del asentimiento de los administrados, pues era ella misma la única intérprete del "interés público". Esta situación, por supuesto, supone una particular interpretación de la problemática división de poderes inaugurada con la revolución francesa: la autoridad judicial no sólo deja de tener cualquier "injerencia" en la ejecución de la ley, sino que tampoco puede juzgar a la Administración Pública, lo cual dará lugar al nacimiento de

16 Remitimos tan sólo a uno de los artículos seminales sobre el tema: ANNINO, “Soberanías en lucha”, pp. 152-184.

17 Garriga y Lorente, Cádiz. Sobre la ausencia de revolución jurídica, véase también GARrIGA, "Continuidad y cambio", pp. 59-106 y GARriga y Slemian, “Em Trajes”, p. 187. 
la llamada "justicia administrativa". Mediante ella, la Administración Pública puede juzgarse a sí misma en cualquier conflicto con los particulares, precisamente porque ella encarna el interés público. En otras palabras, es garante de sus propias actuaciones ante cualquier contencioso, habiendo creado así una autoridad autónoma, exclusiva y superior a la autoridad judicial.

En esta configuración, la Administración Pública rematará paulatinamente su legitimación con el desarrollo del derecho administrativo. Por una parte, éste, sin ser de origen legislativo, sancionó un derecho propio y una jurisdicción especial para los órganos administrativos (la del Consejo de Estado). Por otra parte, como puntualiza, entre otros, Luca Mannori, este "privilegio" permitió establecer procedimientos formalizados para la actuación administrativa, lo cual redujo la discrecionalidad de sus métodos. Así se legitimó el privilegio como "garantía" para los administrados, bajo la forma de recursos ante la jurisdicción administrativa. De esta manera, se constituyó un "Estado legal", en el que los particulares podían impugnar la legalidad de los actos administrativos, pero no la superioridad de los derechos de los órganos administrativos sobre los derechos e intereses particulares. ${ }^{18}$

En contraste, la supervivencia de la concepción jurisdiccional implica que, en el mundo hispánico, se dio una interpretación diferente de la división de poderes: no se desconfió de la autoridad judicial, sino de la vía gubernativa. Esta desconfianza se basaba en la idea de que, al evitar la justicia ordinaria en nombre de la justicia superior del rey, el uso de la vía gubernativa podía fácilmente rayar en "despotismo". Por lo tanto, para no caer en el despotismo y garantizar lo que se entendía como una verdadera separación de poderes, era necesario que la vía gubernativa

${ }^{18}$ Recordemos que dicho Estado legal se autocalificó como Estado de Derecho en el siglo xix. Véase la síntesis elaborada por Mannori y Sordi, Storia, parte cuarta. En este mismo trabajo también se matiza el carácter modélico del caso francés. 
no pudiera desligarse por completo de la justicia ordinaria. Con esto se despojaba a la vía gubernativa del elemento que antiguamente garantizaba sus acciones, la justicia superior, evitando así que se transformara, como en el caso francés, en un poder ejecutivo autónomo. Así, la nueva autoridad judicial se colocó por encima de las nuevas autoridades gubernativas, lo que constituye prácticamente una inversión de lo ocurrido en Francia. ${ }^{19}$ En efecto, la supervivencia de una concepción jurisdiccional del poder significa, ante todo, que no se concibe, porque no es concebible, ninguna Administración Pública, ninguna autoridad que monopolice un poder ejecutivo, es decir, que sea a la vez juez y parte en los asuntos de gobierno. En su lugar lo que encontramos es una serie de autoridades gubernativas que son personalmente responsables de sus acciones, lo que significa que estas autoridades siempre podrán ser cuestionadas y llevadas ante la justicia. ${ }^{20}$

Empero, es necesario destacar que la concepción jurisdiccional tampoco se mantuvo incólume con la separación de poderes, justamente porque la revolución política hizo desaparecer al rey que, en cuanto juez superior, era el garante último de la justicia. Por lo tanto, la pregunta a la que buscaremos dar respuesta es la siguiente: ¿cómo se estructura y concentra el poder cuando la autoridad ya no es puramente jurisdiccional, pero tampoco ejecutiva-administrativa? Dicho de otra forma: ¿ cómo funciona la vía gubernativa, que es ejecutoria -lo que significa que puede

19 Véase la sintética comparación entre el caso francés y el mundo hispánico por Lorente, quien concibe lo que presentamos como la interpretación hispánica como una separación de potestades sin división: LoRenTe, "División de poderes", pp. 307-341. Véase también Brondino, "La vía gubernativa", p. 1025. Por otra parte, es esclarecedor el intento de establecer el contenciosoadministrativo en México a mediados de la década 1850: véase LiRA, "Lo contencioso", pp. 289-319 y LempérIÈRe, “Du juridique”, pp. 409-420. Más comentarios sobre esta configuración hispánica por la misma autora en “Constitution, juridiction”, pp. 1-43. Desafortunadamente, este último ensayo sólo hemos podido consultarlo tras finalizar la redacción del presente trabajo. 20 Véase, en particular, Garriga y Lorente, Cádiz, cap. 7. 
actuar sin la intervención de la justicia-, una vez que ha quedado "huérfana” de su garantía judicial y sin haber adquirido el carácter incontestable de la Administración Pública? Lo que buscaremos mostrar es, en suma, cómo se utilizó la cultura jurisdiccional para dotar de autoridad a la vía gubernativa sin llegar a convertirla en un poder ejecutivo autónomo.

El subdelegado de cuño borbónico, en cuanto comisario judicial del rey, que se insertó y adaptó al marco republicano, es muy útil para analizar la evolución concreta de la vía gubernativa a autoridad gubernativa. Su conservación supuso diversos experimentos, hasta desembocar en el jefe político, comisario gubernativo de nombramiento gubernamental. Al abarcar un largo periodo que va desde la adaptación de la figura del subdelegado en el marco gaditano hasta la inserción definitiva del jefe político en el sistema de gobierno yucateco por la legislación de 1841 , no se pretende proponer un estudio exhaustivo de su función. Como dijimos, sólo se trata de poner de relieve la mutación de la cultura jurisdiccional, las modalidades de consolidación de una autoridad gubernativa y su aporte al nuevo dispositivo de la jefatura política como agente principal de concentración del poder a nivel de los partidos.

Ahora bien, ya es sabido que los subdelegados borbónicos se mantuvieron en más de un caso en el marco gaditano que contemplaba su virtual desaparición, y algunos trabajos han empezado a investigar su papel en el contexto gaditano. ${ }^{21}$ Sin embargo, en el estado de Yucatán, su inserción y adaptación al nuevo orden constitucional se prolonga en el periodo republicano. Esta supervivencia contrasta con su evolución en aquellos

${ }^{21}$ Jáuregui, La Real Hacienda; Diego-Fernández Sotelo, Gutiérrez Lorenzo y Arrioja Díaz Viruell, De reinos; Diego-Fernández Sotelo y Gutiérrez Lorenzo, “El régimen subdelegacional”, pp. 209-232. AlcauTER, "Subdelegados", pp. 1-36. No podremos ahondar en el corto espacio de este artículo en la comparación del caso yucateco con los trabajados en estas referencias. 
estados en donde se procedió más rápidamente a su desaparición o drástica pérdida de facultades, y a su reemplazo por los jefes políticos, a más tardar en las primeras normativas de la época independiente. En efecto, hasta 1829, por poco menos de dos años, y luego a partir de 1834, aparecen en Yucatán los jefes políticos, que por unos años más siguieron siendo también subdelegados. Esta permanencia prolongada de una figura antigua en el "nuevo régimen" permite seguir y analizar la conformación de la autoridad del nuevo Gobierno de manera tal vez más esclarecedora y matizada que a partir de las regiones en las que ha sido rápidamente reemplazada por el jefe político. Además, distingue a Yucatán de los estados federados en los que, con o sin jefes políticos, los alcaldes retuvieron la función judicial. ${ }^{22}$ Esta distinción permite observar una forma de control de lo local que no optó por inventar nuevas autoridades gubernativas -como los jefes políticos-, sino que conservó y adaptó la función judicial de los subdelegados para consolidar la autoridad gubernativa.

Al enfocarnos en la cuestión de la autoridad gubernativa, en el marco limitado de este artículo, apenas podremos apuntar a algunas otras de las muchas aristas de la separación entre justicia y gobierno, así como a la evolución del sistema de gobierno que pone al subdelegado y al jefe político a su servicio. Por ejemplo, mencionemos tan sólo la dimensión territorial del gobierno que plantean directamente estas dos figuras, y cuya redefinición también es de carácter electoral.

Destacaremos, en primer lugar, algunos rasgos fundamentales del gobierno del subdelegado borbónico enraizado en una concepción jurisdiccional del mando, a pesar del desarrollo de la vía gubernativa. En un segundo apartado, daremos seguimiento a diversas transformaciones de su proceder en el contexto de la separación entre gobierno y justicia, y de la nueva soberanía popular-capitalizada por los cuerpos municipales-. Con esto se

22 Véanse varios casos en RoJAs, "El gobierno de los pueblos”, pp. 381-415. 
busca aclarar el alcance y la lógica que preside al nuevo gobierno ejecutorio con miras a la concentración de su autoridad gubernativa. Gracias a ello, en un tercer apartado podremos aquilatar en qué medida el jefe político marcó un hito en cuanto a dicho objetivo, al consolidar también una concepción gubernativa, más que estatal, de la autoridad.

Lo anterior se efectuará tratando de salvar el obstáculo de la poca información conservada en los archivos sobre el periodo. Por lo mismo, no se ha podido ahondar en muchos aspectos de este proceso. Pese a las dificultades, el estudio de los subdelegados y jefes políticos permite colocar el planteamiento de la naturaleza de la autoridad coactiva legítima allí donde lo coloca la supervivencia de la cultura jurisdiccional, ajena a la jerarquización ejecutiva que concibe una cadena de mando continua desde arriba hacia abajo. Al mismo tiempo, subdelegados y jefes políticos constituyen los delegados del rey, y luego del gobernador, más cercanos a los cuerpos territoriales y a la población en general, lo que nos permite indagar sobre cómo se plasma la autoridad del Gobierno en su ejercicio más concreto.

\section{ANTECEDENTE: “EL GOBIERNO DE LA JUSTICIA” \\ POR EL SUBDELEGADO}

Los subdelegados se instalaron, en el marco de las reformas borbónicas, por la Real Ordenanza de Intendentes de 1786. Pese a que todavía falta un estudio que permita aquilatar el impacto del sistema intendencial y subdelegacional en la Provincia de Yucatán, ${ }^{23}$ la historiografía existente destaca la concentración de poder que genera este sistema, abriendo, como dijimos, una brecha en "el Estado jurisdiccional puro". ${ }^{24}$ En una provincia donde anteriormente no hubo corregidores ni alcaldes mayores,

${ }^{23}$ En preparación por Laura Machuca, CIESAs-Peninsular.

${ }^{24}$ Retomamos la expresión de MANNORI y Sord, Storia, p. 128. 
los subdelegados son una innovación o, por lo menos, formalizan muchas de las funciones que antes aseguraban los capitanes a guerra.

En efecto, como mandó la Real Ordenanza, en los partidos de población mayoritariamente española o mestiza, los subdelegados se encargaron de las causas de Hacienda y Guerra, mientras que en los partidos de población mayoritariamente indígena se ocuparon de las cuatro causas, esto es, también de Policía y Justicia. La población de Yucatán era en su mayoría indígena en 10 de los 15 partidos existentes en $1795,{ }^{25}$ que además eran los de mayor densidad poblacional, por lo cual en ellos a los subdelegados se les encomendaron las cuatro causas. ${ }^{26}$

La concentración de poder que generó lo anterior se percibe, antes que nada, en términos de jurisdicción territoriales. La jurisdicción de los tres ayuntamientos yucatecos -Mérida, Campeche y Valladolid- se vio reducida a la traza de la ciudad o villa. ${ }^{27}$ Como han mostrado varias investigaciones, ello modificó sobre todo los equilibrios seculares entre diversos grupos españoles, pues los subdelegados y sus subalternos (los tenientes y los jueces españoles) tomaron el lugar del personal de los ayuntamientos y del clero en los pueblos de indios. ${ }^{28}$ Se convirtieron, así, en el primer referente español para estos pueblos. $\mathrm{Al}$ respecto, hay que recordar que el control de la población indígena fue fundamental para la provincia ya que era la fuente

\footnotetext{
${ }^{25}$ Concretamente, se trata de diez subdelegados. En los demás partidos, el teniente del rey de Campeche, los gobernadores de la provincia de Tabasco, presidios del Carmen y Bacalar se consideran subdelegados.

${ }_{26}$ En este artículo, nos referimos principalmente a estos casos, con algunas referencias puntuales a los demás.

27 Con los matices que caben. Véase Machuca, "El cabildo" [en prensa].

28 Entre otros, Bellingeri, "De una constitución”, pp. 49-78; PACHEco, "Los subdelegados”, pp. 59-69; GüÉmez, Mayas, cap. 1; Jorge Castillo Canché, "El subdelegado borbónico en Yucatán y sus funciones de justicia y policía: el caso de Gregorio Quintana en la subdelegación de la Sierra”, Congreso Internacional de Cultura Maya, Mérida, 2011, inédito.
} 
directa y principal de extracción de riquezas. Se ha subrayado que los subdelegados se convirtieron en los únicos cobradores de los diversos impuestos civiles (destacando el tributo) y religiosos de los indios, para la percepción de los cuales los demás españoles debían ahora acudir a ellos. A ello se suma la formalización del control de los subdelegados de los mandamientos de indios, dispositivo fundamental para la captación de mano de obra, lo cual también generó el descontento de los labradores cuando se vieron desfavorecidos.

Por todo ello, las críticas a los subdelegados surgieron, sobre todo, de parte de los sectores españoles perjudicados en el control y distribución de los caudales y de la mano de obra indígenas. Respecto a los ayuntamientos, por ejemplo, los de Campeche y Valladolid se resistieron a la instalación de subdelegados, mientras que los capitulares de Mérida adoptaron la estrategia de convenir el nombramiento de los subdelegados de entre los miembros de sus redes familiares y clientelares. ${ }^{29}$

Lo que para estos ayuntamientos significó una pérdida de poder, la corona lo concibió como una forma de extracción de riquezas gracias a la contribución de los cuerpos, como remedio de los abusos de los jueces ordinarios y, más en general, como una estrategia para disciplinar a las diversas corporaciones. No fue un intento de sustituir el entramado corporativo por un incipiente aparato burocrático real. Y en ello se cifra precisamente el tema que nos interesa, la forma que toma "el gobierno de la justicia" de los subdelegados.

En este sentido, lo que importa en el hecho de que los subdelegados se ocuparan de las cuatro causas no es sólo la acumulación de ámbitos de actividad, sino la forma de manejarlos. Por medio de los subdelegados avanzó la vía gubernativa, usada por la corona en el periodo borbónico como "potestad económica

29 Entre otros, Campos García, “Que los yucatecos”, cap. 1; Augeron, “Las grandes familias", pp. 91-119. 
y política” extraordinaria, por analogía con la de los regidores en los asuntos económicos de sus pueblos o la del padre con su familia. ${ }^{30}$ Esta vía gubernativa era más expedita que la vía ordinaria porque funcionaba inaudita causa -es decir, sin contradictorio previo- y porque suponía que no se agraviaban derechos o intereses. Sus decisiones eran ejecutorias porque se tomaban “sin conocimiento de causa", al contrario de lo que ocurría en la vía ordinaria. De esta vía gubernativa fueron investidos los subdelegados para conseguir la "felicidad pública”, de la cual comenzó a ocuparse la corona sin pasar por los procedimientos de la jurisdicción ordinaria, a pesar de asociar siempre policía y justicia en la consecución de dicha felicidad. ${ }^{31}$

Ahora bien, precisamente porque se trata todavía de un mundo fundamentalmente jurisdiccional, esta vía gubernativa siempre podía devenir en judicial o contenciosa, en el caso de que surgiera algún reclamo o recurso por daño a derechos adquiridos o incluso por otras circunstancias. Ante los recursos, la jurisdicción extraordinaria siempre se podía imponer en virtud de ser una forma de justicia superior. Su uso cada vez más frecuente generó lo que fue denunciado como arbitrariedad o despotismo. No obstante, al conservarse como extraordinaria sin convertirse en "principio monárquico", ${ }^{32}$ se mantuvo -ya se mencionó-, "en un lugar marginal del discurso" 33 de cuño jurisdiccional, justificándose por éste y sin ponerlo en duda.

Por lo tanto, lo que hay que destacar para nuestro tema no es tanto el avance de un gobierno de "mano dura", sino que el desarrollo de la vía gubernativa conllevó, bajo la recomendación

30 Clavero, “Tutela administrativa”, pp. 419-468; AgüEro, “Las categorías”, pp. 19-58.

31 De ahí, por ejemplo, que las causas de policía y justicia marcharan tan juntas en la Real Ordenanza, por ejemplo $\$ 57$, pp. 197-198.

32 Clavero, “Tutela administrativa”, pp. 419-468, y Mannori y Sordi, Storia.

33 AgüEro, “Las categorías”, p. 55. 
de las propias instancias reales superiores, el desarrollo de prácticas consensuales. ${ }^{34}$ Es decir, el desarrollo de formas de acuerdo no judicializadas, negociaciones informales. Éstas servían, precisamente, para evitar recursos judiciales que entorpecían la vía expedita. Así, a la sombra de la Justicia, se fueron desarrollando y consolidando prácticas informales de negociación que no se conceptualizaron como administrativas, pues su legitimidad no dependía de ellas mismas.

Un ejemplo de esta forma de proceder gubernativa y de su legitimidad amarrada a la jurisdicción, lo encontramos en una serie de constancias que, tan tardíamente como 1811, enviaron diversos párrocos, repúblicas de indios, vecinos principales y oficiales de milicias a un subdelegado al final de su servicio. ${ }^{35}$ En estos documentos, destaca el espíritu de la época, pues se pone de relieve la actividad del subdelegado en materia de policía y fomento, siendo esta materia la novedad más llamativa de la que es instrumento el subdelegado en los partidos. En diversos pueblos, nos indican las fuentes, el subdelegado en cuestión ha hecho reponer la noria y reparar el cuartel o la audiencia en la que se alojan los viajeros; ha hecho abrir una carnicería y asegurado la limpieza de calles y caminos; ha hecho adelantar la industria y el comercio, y ha apoyado a los pobladores que han querido construir casas de mampostería, etc. Incluso, las constancias hablan de "su aptitud sin igual en agenciar y acopiar granos para el socorro de la ciudad de Mérida y pósitos de este

34 Garriga, “Gobierno y justicia”, pp. 69 y 108.

35 Se trata del partido de Sierra Alta, donde el subdelegado suma las cuatro causas. Francisco Ortiz fue subdelegado de Sierra Alta de 1805 a 1810. El quinquenio siguiente fue adjudicado a José Castellanos. En 1815, cuando estaba por finalizar, Ortiz fue agraciado con un nuevo quinquenio; pero, entre tanto, Castellanos pidió una prórroga de dos años porque el primer "periodo constitucional le interrumpió sus atribuciones”, prórroga que le concedió el gobernador Castro y Araoz aun antes de avisar a la superioridad. Además, Miguel Bolio alegó haber recibido la misma gracia que Ortiz. Éste terminará volviendo a ocupar el cargo. AGN, I, vol. 54, exp. 1, 130 ff. 
pueblo, muy particularmente el año pasado que fue en fuerza de la mayor hambre [...]: consiguió comprarle a los pudientes". Al velar ahora por los pósitos de los pueblos, si éstos han perdido autonomía, el papel del subdelegado es asegurar el bienestar de la población encargándose de redistribuir correctamente las existencias. Todo ello indica que el subdelegado tomó "providencias gubernativas" que concernían a lo que antes, por lo menos en parte, era asunto económico de los pueblos.

Por otro lado, en estas actividades, despunta la colaboración entre las iniciativas del subdelegado y la propia población, que se encargó materialmente de limpiar, reparar, construir, acarrear materiales y granos, etc. -en suma, de toda la organización de los pueblos ahora bajo la tutela del subdelegado-. Lo que destacan los diversos firmantes de dichas constancias no es sólo la "utilidad" de las iniciativas del subdelegado, que para ellos son "beneficios al común", sino las dos caras de este proceder gubernativo: por una parte, la tutela de un padre con sus hijos ("como amante y protector de los pueblos") que no rinde justicia, sino que disciplina a menores de edad. Este método paternalista contrasta con el trato dado a meros "súbditos" que tendrían que sufrir la ejecución sin margen de negociación. Y, por otra parte, las constancias insisten en que las obras y el quehacer en general del subdelegado no han generado "agravios" -es decir, la utilidad general que ha promovido no ha sido contradicha por ningún derecho adquirido.

El marco justiciero de la labor del subdelegado se reitera en relación con el cobro de diversos impuestos: según la república de Oxkutzcab, el subdelegado ha cobrado durante cinco años "sin perjuicio" ni en tributos, ni en comunidad, ni en bolpatán. Prosiguen diciendo que no sólo no hubo "extorsión, sino que lo verificaba con amor y así lo que pedía lo cumplimos", variante de la "suavidad" general de su gobierno. El "amor" y la "suavidad" remiten a la vieja práctica de los arreglos informales con los indígenas en el cobro y en la aplicación de determinadas 
superficies de cultivo. Concretamente, el subdelegado no "ejecuta" sistemáticamente a los caciques en caso de entrega insatisfactoria, como sí podía hacerse en virtud de la facultad económico-coactiva dada a los cobradores por la Real Ordenanza; tampoco "ejecuta" sistemáticamente a los caciques que no cumplen con las superficies mandadas cultivar para asegurar el pago del tributo. ${ }^{36}$ Ello, por supuesto, significa, antes que nada, que se consolidan prácticas informales en las relaciones con las repúblicas de indios, lo que les otorga a los subdelegados un amplio margen de maniobra respecto a pagos y labores indígenas a los que aspiraban también los curas y los labradores.

Y, por último, las constancias hacen hincapié en que el subdelegado, en su papel de juez, es decir, en el ámbito contencioso, ha aunado a la justicia la "humanidad" y la "misericordia" -la toma en cuenta de las circunstancias y no sólo de las normas, para emitir decisiones más justas, dando, como se recuerda, “a cada uno lo suyo". ${ }^{37}$

En suma, este retrato del subdelegado ideal permite ver la permanencia discursiva de la horizontalidad de las relaciones de autoridad concebidas como relaciones de justicia: todas las actuaciones "gubernativas" del subdelegado en pro de la "utilidad pública" son valoradas por no perjudicar a ningún individuo, común o fondo. En el mismo expediente, el propio subdelegado insiste en que, a lo largo de sus cinco años de gobierno, no ha generado queja alguna. Ante las posibles "vejaciones” y "extorsiones" de los subdelegados, las propias reglamentaciones de los gobernadores se justifican con el objetivo de "evitar recursos"38 provenientes -no tanto, o no solo- de las repúblicas de indios, sino también de los sectores españoles.

\footnotetext{
36 Véase, por ejemplo, la insistencia del gobernador para que así lo hagan los subdelegados en 1807, AGEY, C, CG, vol. 1, exp. 2-A, s/f, 1807.

37 Recordemos que, al establecerse los subdelegados, los indígenas también comenzaron a acudir a ellos en vez del Juzgado de Indios.

38 Por ejemplo, AGEY, C, CG, vol. 1, exp. 2-A, s/f, 1807.
} 
Ahora bien, ya fueran "suaves" o "rigurosos", estos procedimientos no judiciales estaban garantizados, en última instancia, por la justicia superior del rey. De nuevo, esto significa que, aunque se podían recurrir de muchas maneras, el subdelegado estaba respaldado por una justicia superior que podía hacerse "absoluta" en nombre de la "utilidad pública", lo que-diríamos hoy- podría comprimir los derechos de los particulares. Por eso mismo, al igual que en otros expedientes, se puede apreciar el poco peso que tuvieron estas constancias en favor de las pretensiones del subdelegado para volver a ocupar el cargo. En términos actuales, más que los derechos de los gobernados, contó el interés de la Real Hacienda (que todavía no era pública, pero cuyo titular se ocupaba ya de lo público): lo que importó fue que el subdelegado cedió una fuerte suma a la Real Hacienda, a modo de fianza. ${ }^{39}$ Por último, subrayemos cómo esta misma forma reservada y el criterio aplicado impulsaron o consolidaron procedimientos extrajudiciales que ya gozaban de buena salud en Yucatán, según los críticos, por la lejanía de las instancias judiciales superiores. ${ }^{40}$

39 Ortiz cedió 3836 pesos a la Real Hacienda; de hecho, en este caso, la consulta del asesor precisa que, al no otorgársele la subdelegación a Ortiz, la Real Hacienda debería devolverle dicha suma. Mencionemos también que estas constancias funcionan como un juicio de residencia al revés: alegan los derechos no perjudicados. Sin embargo, aunque constan visitas secretas acompañadas de otras "públicas" (véase el conocido expediente formado a raíz de la acusación del ayuntamiento de Campeche "contra todos los subdelegados que ocupan los partidos de esta Provincia”, AGN, $A H H$, vol. 1064, exp. 18), y para esas fechas tardías se seguían recibiendo quejas judiciales; desde hacía años el gobierno virreinal ya no aplicaba juicios de residencia a los subdelegados, ateniéndose, al finalizar el quinquenio de un subdelegado, a los eventuales agravios causados a la Real Hacienda (agradezco a José Luis Alcauter y a Laura Machuca por esta precisión). Es decir, aunque el interés público no está identificado del todo con el interés real, frente al interés superior, los intereses particulares y corporativos tendían a menguar.

40 Véanse, por ejemplo, las Instrucciones del Capitán General de Yucatán de 1810, transcritas en Campos García y Domínguez Saldívar, La Diputación 
EL SUBDELEGADO DE HACIENDA Y JUEZ DE PRIMERA INSTANCIA: LA SEPARACIÓN Y UNIÓN DEL GOBIERNO Y DE LA JUSTICA EN EL PARTIDO

En este apartado abordaremos la mutación del cargo y su funcionamiento desde la primera publicación de la Carta gaditana hasta la primera instalación de jefaturas políticas, en noviembre de 1829, aunque con dicha instalación no desapareció el subdelegado. La legislación gaditana rigió en Yucatán de octubre de 1812 hasta su abolición el 24 de julio de 1814, y luego a partir de 1820 hasta la gradual aparición de la nueva Constitución y nueva legislación, elaboradas por el Congreso Constituyente que comenzó sus labores en agosto de 1823 -proceso que, como en el resto del país, dejó vigente buena parte de la legislación gaditana.

Comenzaremos por ver cómo se reorganiza el gobierno separado de la justicia, para después aquilatar las estrategias que se ensayaron para compensar dicha separación, la cual incidió en el devenir de la propia vía gubernativa.

El acotamiento de las atribuciones gubernativas del subdelegado

Como en otras regiones, la legislación gaditana estrena la llamada municipalización del poder. ${ }^{41}$ En principio, el nuevo ejecutivo ejerce mucho más que la tutela antigua, pues los nuevos ayuntamientos son despojados de su carácter de órganos de autogobierno y su manejo municipal queda sujeto a la aprobación del titular del ejecutivo -el jefe superior político y luego el gobernador-, en muchos puntos de forma conjunta con la diputación provincial (y luego el Congreso). Empero, para los pueblos esto

Provincial en Yucatán, p. 255.

41 Domínguez Saldívar, Liberalismo. 
significó librarse de la tutela de los subdelegados, pues muchas poblaciones adquirieron ayuntamientos por primera vez (pasando de 3 a 156 en 1814), lo que les permitió "reasumir" varias atribuciones económico-gubernativas anteriormente en manos de los subdelegados. Sobre todo, en virtud de que la legislación gaditana transformó a los ayuntamientos en nuevos "agentes del poder Ejecutivo", ${ }^{42}$ no estableció un aparato burocrático o comisarial, dejando entonces toda "ejecución" en manos de órganos de elección popular.

Pese a que en Cádiz se aclaró que la elección popular de los ayuntamientos no redundaba en representación política, lo cierto es que dicha elección se interpretó como representación en la que se cifraba la nueva soberanía. Y por ello en Yucatán, como en otras partes, se expresan repetidas veces quejas contra ayuntamientos sumidos en la "indolencia y apatía" en todos los ámbitos gubernativos, actitud que se explicó por estar los regidores “engreídos con su representación”, además de por su ignorancia. La Junta Provisional Gubernativa ${ }^{43}$ de 1823 se

${ }^{42}$ Diario de sesiones, Sesión del 10 de enero de 1812, p. 2590. Aprovechamos esta expresión que el Conde de Toreno usó más bien para explicitar la sujeción jerárquica de los ayuntamientos, precisamente para subrayar que por mucho que se apelara a una nueva relación de autoridad, no se concibió la creación de una nueva planta burocrática de funcionarios nombrados por el gobierno. ${ }^{43}$ La Junta Provisional Gubernativa -significativamente también llamada Ejecutiva y autocalificada de Poder Ejecutivo- se establece de manera transitoria en la perspectiva del establecimiento de los tres poderes en el marco constitucional por el Congreso Constituyente. En este contexto, se termina cancelando la figura del jefe superior político "por innecesaria" (19 de febrero de 1824) y la Junta sigue trabajando con la Diputación Provincial cuya autoridad se declara ahora puramente "administrativa". Posteriormente, con la cancelación de la diputación provincial, se entiende que la junta asumirá sus funciones; el Congreso constituyente nombra a un gobernador interino el 23 de abril. Se mantiene también el intendente, ahora sujeto a la junta, hasta que se establezca un tesorero general, en enero de 1825. Aunque los miembros de la junta fueron elegidos por voto popular, ella subraya en su correspondencia su debilidad por la perspectiva inmediata de elección de un gobernador. Otro 
queja de que se pasó de una "administración arbitraria" (la de los subdelegados) a una "despótica” por reputarse los ayuntamientos "dueños absolutos". ${ }^{44}$ Es interesante que califique de despóticos a los ayuntamientos pues significa precisamente eso: la representación popular (de los ayuntamientos) funge aquí como sustituto de lo que se perdió, la garantía judicial (del rey). Como en otras partes, las modificaciones al "gobierno de los pueblos" siempre se justificaron con el argumento de la "apatía" de los ayuntamientos y, como en otras partes, una de las medidas principales en la primera organización del periodo independiente fue la drástica reducción de su número.

Sin embargo, la llamada libertad municipal fue enfrentada por el Gobierno del "nuevo régimen" yucateco con su antigua herramienta, los subdelegados, que fungieron como barrera de contención. Según el conocido decreto de 9 de octubre de 1812, los subdelegados serían reemplazados por jueces de primera instancia que tenían que ser letrados, mientras que para el gobierno de los pueblos, de nuevo, los "agentes del ejecutivo" serían los ayuntamientos, dejando la posibilidad de establecer jefes políticos subalternos. ${ }^{45}$ Por lo tanto, los subdelegados dejaron de ser, en principio, jueces y agentes gubernativos. No obstante, lograron permanecer con cierta naturalidad gracias al espíritu no rupturista gaditano, que cancelaba sólo virtualmente todo lo antiguo que fuera incompatible con el nuevo orden. ${ }^{46}$

achaque debido al carácter preeminentemente congresista del gobierno en esta etapa, es puesto de relieve en el estudio de su funcionamiento por QuEzADA, Bock y Hernández Ortiz, Orígenes.

${ }^{44} \mathrm{BY}$, "Libro copiador de la correspondencia de la Junta Provisional Ejecutiva de la Provincia de Yucatán”, LMEP-110, fs. 49v.-51v., 1823.

${ }^{45}$ En los puertos de mar y "en las capitales de partido de provincias muy dilatadas o muy pobladas": "Instrucción para el gobierno económico-político de las provincias”, 13 de junio de 1813, Colección de los decretos, t. IV, cap. 3, art. 3, p. 118.

${ }^{46} \mathrm{Su}$ supervivencia, por lo menos temporal, ya se contemplaba en el decreto del 18 de marzo que mandó a todas las autoridades existentes jurar y 
En efecto, en Yucatán se conservaron en virtud de que el citado decreto señaló que, en tanto no se crearan los nuevos distritos judiciales, los subdelegados de ultramar se mantendrían como jueces de primera instancia. ${ }^{47}$

A continuación daremos un panorama de la drástica reducción de las atribuciones de los subdelegados. También se mostrará que la recuperación o mantenimiento de algunas de sus funciones, más que construir un nuevo cuerpo burocrático que concentrara el poder ejecutivo, permitió estirar lo más posible la antigua organización del gobierno para insertarla en el nuevo marco constitucional, lo que tuvo efectos en la constitución de una "autoridad ejecutiva".

Lo que salta a la vista, en particular en el primer periodo gaditano, es la exclusión de los subdelegados del ámbito gubernativo. En diversos correos de los gobernadores se aclara que éstos no pueden presidir los ayuntamientos, que "lo gubernativo, económico y de policía" no les incumbe porque no son "jefes políticos subalternos" y que, en su defecto, lo son los alcaldes constitucionales. ${ }^{48}$ Ciertamente, en cuanto al ámbito de "lo gubernativo, económico y de policía”, la correspondencia de los gobernadores se dirige sobre todo a los ayuntamientos y a los alcaldes, y las leyes las circulan los alcaldes de las cabeceras de partido a los demás alcaldes. Incluso la problemática distinción entre ámbito municipal y "general" excluye a los subdelegados, pues el ámbito general-se precisa en cuanto a la reparación de caminos en 1814- "corresponde al jefe político superior con solo la intervención que éste

\footnotetext{
encargarse de la jura de la Constitución. Véase Alcauter, "Normas", p. 125. 47 "Decreto. Reglamento de las Audiencias y Juzgados de primera instancia", 9 de octubre de 1812, Colección de los decretos, t. III, p. 120.

48 AGEY, C, CA, "Copiador de la correspondencia del subdelegado de Bolonchencauich y de sus ayuntamientos anexos", vol. 1, exp. 7A, f. 2, 1813 y AGEY, C, CG, "Copiador de la Correspondencia del Gobernador Artazo y Barral con los subdelegados de intendencia y los ayuntamientos de sus respectivas jurisdicciones", vol. 1, exp. 5, f. 8v., 1813.
} 
le asigne a aquéllos (los ayuntamientos)" ${ }^{49}$ En cuanto a la reorganización de diversos servicios antes asegurados únicamente por los indígenas, los subdelegados pierden su papel central de distribuidores de mano de obra. Por ejemplo, en la desorganización que resultó de la cancelación de las repúblicas (y el rechazo de muchos antiguos vecinos a asumir nuevas faginas de policía), los subdelegados de Calkiní y Tekax enviaron "un reglamento para el gobierno económico de los pueblos de la provincia" a la Diputación Provincial; pero ésta en lugar de asumirlo lo pasó a los correspondientes ayuntamientos "para que adapten lo que convenga en las ordenanzas municipales" que todavía no habían formado. ${ }^{50}$ Los ejemplos anteriores muestran la constante reiteración de los límites de los subdelegados, lo que a su vez revela la resistencia de éstos a desprenderse de sus antiguos ámbitos de poder; también muestran la voluntad del Gobierno de hacer respetar las restricciones, claramente forzada por la presión política de los ayuntamientos.

Pese a lo anterior, los subdelegados eran el único elemento comisarial que se aprovechó casi de inmediato para suplir a los ayuntamientos cuando su insubordinación o impotencia (sobre la que volveremos) era extrema. Por ejemplo, ante la protesta de un ayuntamiento porque el gobernador seguía transmitiendo las órdenes por medio del subdelegado, el gobernador contestó que se hacía así porque el ayuntamiento en cuestión ni siquiera había comunicado su instalación..$^{51} \mathrm{El}$ subdelegado reapareció, pues, como una herramienta gubernativa sobre todo en la esfera "general" de gobierno, lo cual muchas veces supuso la colaboración con los ayuntamientos y, en ocasiones, fue una forma de

\footnotetext{
${ }^{49}$ Sesión del 28 de marzo de 1814, La Diputación Provincial de Yucatán, p. 239.

${ }^{50}$ Sesión del 14 de junio de 1814, La Diputación Provincial de Yucatán, p. 299. 51 AGEY, C, CG, "Copiador de la correspondencia del Gobernador con varios ayuntamientos constitucionales de la Provincia”, c. 5, vol. 3, exp. 6, f. $18,1820$.
} 
"compensar" su ineficiencia. Uno de los casos menos conflictivos fue el de la distribución de vacunas en la que los subdelegados conservaron su encargo y terminaron integrando, en más de un caso, las nuevas juntas de sanidad, por lo menos en las cabeceras de partido, sin que ello se formalizara en el reglamento respectivo. En cuanto a la formación de la estadística, desde 1813 "con el objeto de que ayuden a los ayuntamientos para las noticias que deben suministrar a la estadística”, la diputación provincial nombró, entre otros, a varios subdelegados. ${ }^{52}$ Como para 1824 muchos ayuntamientos todavía no habían enviado los datos requeridos, y la diputación provincial necesitaba información sobre los pueblos y su población, se pidió esta información a los subdelegados "entre tanto esto (la estadística) se verifica". ${ }^{53}$ En esta situación convergieron, como en otras partes, el hecho de que los subdelegados poseían sus propias redes de información en los partidos, así como el poco interés en que se formara una nueva estadística que supondría la cancelación de los antiguos partidos y el desarreglo de las jerarquías establecidas. ${ }^{54}$

En los hechos, además, los subdelegados fueron aprovechados por el jefe superior político, la Junta Provisional Gubernativa y luego el gobernador, si no como agentes, sí como instrumentos gubernativos precisamente para tratar de imponer la jerarquización que no se formuló cabalmente en Cádiz. Desde 1814, al imponer multas a los ayuntamientos por no cumplir con sus atribuciones, el Gobierno las hizo efectivas a través de los subdelegados. ${ }^{55}$ Esto se consolidó en 1825 en un reglamento de policía

52 Sesión del 18 de junio de 1813, La Diputación Provincial de Yucatán, p. 97. 53 Sesión del 28 de septiembre de 1824, El Primer Congreso, p. 509.

54 Insiste en esto para Yucatán, Campos García, "Justicia Pretoriana”, pp. 33-38.

55 Por ejemplo, la multa al ayuntamiento de Ticul por "haber procedido sin autoridad y saliendo de la esfera de sus atribuciones a suspender los maestros de escuela”, sesión del 14 de abril de 1821, La Diputación Provincial de Yucatán, p. 598. 
que seguía dividiendo policía general, a cargo del Gobierno, y policía de los pueblos, a cargo de los alcaldes y ayuntamientos, sin presentar ninguna figura intermedia, pero con una serie de multas que amenazaban a alcaldes y ayuntamientos y que, claramente, serían ejecutadas por los subdelegados. ${ }^{56}$

En resumen, en la esfera de lo "gubernativo, económico y de policía” los subdelegados se ven excluidos por los únicos agentes oficiales que son los ayuntamientos, pero, de manera ciertamente casuística, vuelven a entrar por medio del Gobierno, bajo cuya autoridad tienen que actuar los ayuntamientos, sea en lo municipal o en lo "general".

Antes de abordar, en el apartado siguiente, el ámbito por el que se les reintegra más claramente a "lo gubernativo, económico y de policía", hay que puntualizar el límite más notable de este "jefe político subalterno" intermitente, el límite más estrictamente político. Por ejemplo, en 1813, se comisiona a un subdelegado "como jefe político" para dar posesión a un ayuntamiento constitucional. ${ }^{57} \mathrm{~A}$ otro incluso se le manda publicar y hacer jurar la Constitución..$^{58}$ Sin embargo, estas comisiones

56 "Decreto. Reglamento de policía”, 3 de octubre de 1825, Colección de Leyes, t. II, pp. 8-13.

57 Por ejemplo, Sesión del 30 de abril de 1813, La Diputación Provincial de Yucatán, p. 63. También algunos envían los resultados de las elecciones concejiles, por ejemplo, AGEY, C, CG, "Copiador de la correspondencia del gobernador Artazo con el subdelegado y otras autoridades del Partido. Tekax", vol. 2, exp. 13, fs. 9v.-10, 1814. En el segundo periodo gaditano, se encarga a los jueces españoles que posesionen a los ayuntamientos constitucionales, excepto donde ya no hubo en el último periodo colonial, pero donde hubo ayuntamientos preconstitucionales, éstos dan posesión a los constitucionales: AGEY, C, CG, "Copiador de la correspondencia del Gobernador con varios ayuntamientos constitucionales de la Provincia”, c. 5, vol. 3, exp. 6, fs. 2-3, 15, 47, 1820. Por otro lado, no hay que olvidar que, por ejemplo en Campeche, preside el ayuntamiento el teniente del rey.

${ }^{58}$ Por ejemplo, el subdelegado de Izamal publica la Constitución en la cabecera: BY, "Libro copiador de la correspondencia de los pueblos que componen el partido de Izamal. Capitanía de Yucatán”, LMEP-169, s/f, 1820. 
puntuales responden al espíritu no rupturista de Cádiz y confirman la pérdida de atribuciones de los subdelegados, por lo cual en más de una ocasión éstos se resistieron a cumplir ambos encargos. ${ }^{59}$ En todo caso, ni la supervisión que podían ejercer del buen "orden" de las elecciones municipales ${ }^{60}$ redundó en hacerlos agentes del Gobierno. ${ }^{61}$

En la flamante legislación del Yucatán independiente, con la reducción de los ayuntamientos y la degradación de muchos a juntas municipales cuyos alcaldes son elegidos por el gobernador a partir de una terna propuesta por las juntas, los subdelegados tienen que comunicar las ternas informando al gobernador sobre "la aptitud y recomendaciones de dichos individuos". ${ }^{62}$ Esto ha sido interpretado como una reconstitución del antiguo sistema de jueces españoles en los pueblos, los que antes eran propuestos por los subdelegados. ${ }^{63}$ Ello es muestra de la ya mencionada debilidad política del Gobierno ${ }^{64}$ pero también de lo efectivo que podía resultar simplemente reconstituir el sistema anterior (de hecho, en esta lógica se inserta la reconstitución de

59 Por ejemplo, AGEY, C, CG, "Copiador de circulares del gobernador Castro y Araoz con los subdelegados y el teniente del rey", vol. 3, exp. 6-A, f. 5, 1820. Véase también Moreno, "Pueblos y ayuntamientos", pp. 63-71.

60 Por ejemplo, AGEY, PE, CO, "Cuaderno copiador de la correspondencia de los gobernadores a las autoridades de la subdelegación de Sierra Alta", vol. 1, exp. 10, f.1, 1824 .

${ }^{61}$ Como se ve más claramente con la aparición del jefe político del periodo republicano, y como sólo podemos apuntar en las notas 88, 130 y 147, inciden directamente en ello también la modalidad de su nombramiento y de su retribución.

62 "Sobre el régimen económico y juntas municipales", 20 de septiembre 1824, Colección de Leyes, t. I, art. 11, p. 154. Esta precisión que involucra al subdelegado no aparece en la Constitución de 1825.

${ }^{63}$ Añadiendo la continuidad del personal que ocupó el cargo de juez español y el de alcalde de junta municipal, lo cual cabe matizar. Dzul SÁnchez, "Jueces españoles", pp. 73-101.

${ }^{64}$ En muchos casos el Gobierno no logra imponerse incluso en la decisión que le incumbe sobre confirmación o anulación de los resultados electorales. 
unas 200 repúblicas de indios cuyos caciques los elige ahora el gobernador a propuesta de una terna por el subdelegado). Por lo demás, como ahora las ternas para alcaldes son propuestas por las juntas y no por los subdelegados, éstos intentan influir en su elaboración antes de mandarlas al gobernador, así como antes trataban de inmiscuirse en los procedimientos electorales o suspender a los alcaldes encauzados antes de que llegara alguna orden del gobernador. ${ }^{65}$

Lo que nos interesa subrayar aquí son dos aspectos complementarios que favorecieron la permanencia de los subdelegados: por una parte, la reconstrucción de la red gubernativa anterior (en donde tradicionalmente se insertaban) y su (relativa) marginación del ámbito político municipal (lo que los hacía más tolerables para las juntas municipales). Y por otra, como en la Constitución yucateca de 1825 no aparece una definición mínima de sus funciones, los subdelegados resultaron ser un instrumento gubernativo muy maleable.

\section{El avance del subdelegado en un ámbito crucial: la Hacienda pública}

Sin tener por objetivo detallar el reacomodo de la Hacienda Real en Hacienda pública, es necesario abordar la cuestión de la recaudación y el manejo de los caudales, pues es un aspecto fundamental de la insubordinación de los ayuntamientos. Desde el primer periodo gaditano, conforme al artículo 321 de la Constitución, los ayuntamientos hicieron sus propuestas de arbitrios para sufragar sus propios gastos e, inicialmente, los de los diputados a Cortes, así como los de la jefatura política superior y de la Diputación Provincial. Las diversas propuestas redundaron

65 Véase, entre otros, AGEY, PE, $A$, “Diligencias practicadas sobre los hechos violatorios a la ley cometidos en la elección del ayuntamiento de este pueblo”, vol. 1, exp. 23, 1825; AGEY, CG, A, "Libro de acuerdos de la Junta Provisional Gubernativa”, vol. 1, Despacho del 16 de julio de 1823, fs. 12v.-13. 
en el establecimiento, por lo menos para 59 ayuntamientos, de una contribución personal. Con ello se concretó la pérdida por los subdelegados de la percepción de las antiguas contribuciones indígenas, ahora fundidas en la contribución personal. ${ }^{66}$

Los subdelegados se mantuvieron como subdelegados de Hacienda o de rentas, entendiéndose con esto que se limitaban a la percepción de las alcabalas. Pero en el segundo periodo gaditano, tras haber sufrido varias transformaciones, la contribución personal se encargó a los subdelegados, en el cobro y en las cuentas. Los ayuntamientos yucatecos reclamaron el artículo 321 de la Constitución, pero la Diputación Provincial no accedió, con el argumento del aseguramiento de la nueva Hacienda pública, pues los subdelegados ya habían presentado fianzas (volveremos sobre este aspecto). El mismo argumento justificó que se reputaran tesoreros de dichos caudales. ${ }^{67}$ En la misma respuesta, la Diputación Provincial puntualizó que se trataba de “fondos públicos”. En este sentido, el nuevo sistema de cobro, bajo la égida de un elemento comisarial, permitió avanzar en la incorporación y sujeción del ámbito municipal a la "Hacienda pública”. ${ }^{68}$ A partir de ese momento, los subdelegados no sólo revisaron las cuentas de la contribución personal en los ayuntamientos, sino que empezaron a informar sobre cualquier pedido de gasto municipal, aunque esto último no

66 Y también de las obvenciones. Para un recuento detallado de este proceso, véase Hernández Ortiz, "La política fiscal”, pp. 79-87. Una visión más a mediano plazo sobre la estructura fiscal yucateca ya había sido propuesta por Quezada, "Federalismo", pp. 115-120.

${ }_{67}$ Sesión del 21 de diciembre de 1820, La Diputación Provincial de Yucatán, p. 502.

${ }_{68}$ No se trata aquí de analizar cabalmente el papel de los subdelegados en la formación de la Hacienda pública. Señalemos tan sólo que el subdelegado se encargó de otros rubros más. Por ejemplo, desde el primer periodo gaditano se le encargó la recaudación de los arrendamientos municipales, siguiendo una dinámica que aúna suplencia de los ayuntamientos e incorporación de la Hacienda municipal a la pública. 
llegó a sistematizarse. ${ }^{69}$ Por este camino, los subdelegados se convirtieron en instrumento para someter buena parte de "lo económico gubernativo y de policía" municipal a la aprobación del Gobierno. Lo anterior se confirma en la Constitución de 1825 que, sin mencionar a los subdelegados, establece la "inspección del Gobierno, a quien [los ayuntamientos] rendirán cuenta documentada cada año de los caudales públicos que hayan recaudado e invertido". ${ }^{70}$

No obstante, los subdelegados siguieron apoyándose en los cuerpos municipales por lo menos para la formación de los padrones y el cobro - de ahí que las quejas contra los ayuntamientos subsistieran- ${ }^{71}$ Lo que se denunció como "apatía" de los ayuntamientos consistió también en la dificultad de los nuevos cuerpos municipales para cobrar los impuestos tras la cancelación de las repúblicas de indios. De hecho, los propios subdelegados manifestaron las mismas dificultades para el cobro. De ahí que, a partir de 1820, se encargara a los antiguos caciques auxiliar a los subdelegados, subrayando que el cobro no incluía otras facultades anteriores. ${ }^{72}$ A pesar de las medidas coactivas adoptadas en abril de 1824 , que comentaremos a

${ }^{69}$ Por ejemplo, AGEY, CG, $A$, "Libro de acuerdos de la Junta Provisional Gubernativa", vol. 1, Despacho del 11 de junio de 1824, f. 128v.

70 Las constituciones, art. 210, p. 326; véanse también arts. 209 y 212. En la primera legislación del periodo independiente, los subdelegados aparecen en las leyes y decretos relativos a los impuestos y en el reglamento de policía sólo como informantes acerca de los deudores.

${ }^{71}$ En diciembre de 1823, por ejemplo, al quejarse de la "apatía” de los ayuntamientos, la Junta Provisional Gubernativa se refiere más específicamente a dos asuntos: los pósitos, ahora "al borde de su aniquilamiento", y las contribuciones. BY, "Libro copiador de la correspondencia de la Junta Provisional Ejecutiva de la Provincia de Yucatán”, LMEP-110, fs. 50-50v., 1823.

72 "Sin la menor jurisdicción ni autoridad alguna aun económica en los de su Clase, ni otra incumbencia que la de hacer bajo la dirección del Subdelegado el cobro de la Contribución real, Comunidad y Holpatan que deben continuar por ahora”: BY, "Circulares de la Capitanía General y Comandancia Política de la Provincia de Yucatán”, LMEP-156, f. 2, 1820. 
continuación, la Junta Provisional Gubernativa pidió en junio el restablecimiento de las repúblicas de indios para el cobro. ${ }^{73}$ El mismo año, se confirman las repúblicas y a los subdelegados como responsables del cobro, cuando el Congreso constituyente, aun antes de expedir la Constitución, aglutinó diversos impuestos en la contribución personal, la cual encarga a los subdelegados.

En cierto sentido, pues, se ha logrado reconstruir el antiguo sistema de cobro, restableciendo las autoridades y relaciones ahora oficialmente acotadas a la recaudación. Incluso los caciques son seleccionados directamente por los subdelegados para proponerlos en terna al gobernador. ${ }^{74}$ Todo esto permitió afianzar cierta jerarquización en el ámbito fiscal. De hecho, la cuestión del cobro a la población indígena parece ser un elemento clave en la consolidación de la figura subdelegacional en este periodo.

\section{¿Juzgar o ejecutar?}

Las continuidades y avances de los subdelegados en los ámbitos gubernativos analizados no se aquilatan del todo si no se toma en cuenta la lógica que sigue su supervivencia: el hecho de que estos subdelegados también sean jueces de primera instancia, como se recordó anteriormente. El efecto más perceptible de esta segunda función es que limita la dispersión del poder. Su resultado de contención es inmediato: estos jueces fueron despojados de los juicios verbales, ahora asignados a los alcaldes conciliadores, ${ }^{75}$ pero allí donde antiguamente no había alcaldes ordinarios, los

\footnotetext{
73 AGEY, CG, $A$, "Libro de acuerdos de la Junta Provisional Gubernativa", vol. 1, Despacho del 14 de junio de 1824, f. 128v.

${ }^{74}$ Más adelante, se volverán a involucrar también los curas en las propuestas de ternas.

75 Padilla Pérez ha mostrado que buena parte de estos juicios los asumían los jueces españoles (“Ámbitos”); sin embargo, la pérdida de dichos juicios por
} 
subdelegados continuaron como jueces, es decir, en prácticamente todo Yucatán, incluyendo Valladolid, ${ }^{76}$ quedando sólo las excepciones de las ciudades de Mérida y Campeche. ${ }^{77}$ Además, el "mayor honor por considerárseles Jueces Letrados"78 redundó en un aumento muy concreto de su poder, pues a diferencia de la época borbónica, ellos fallan sin mandar los casos instruidos a Mérida o a México.

Sin detallar todos los ámbitos que como jueces pudieron penetrar los subdelegados, nos limitamos a subrayar que esto les permitió, en parte, resarcirse del acotamiento de sus atribuciones gubernativas. En efecto, es de resaltar que llevaban a cabo multitud de averiguaciones, diligencias e informaciones sumarias en todos los ámbitos. Se llaman sumarias puesto que remiten a

los subdelegados sí ha sido registrada como un cambio digno de mencionarse. Por ejemplo, AGN, $I$, vol. 54, exp. 1, 1816, f. 67.

${ }^{76}$ En 1813, Valladolid queda en la misma situación que Mérida y Campeche (por ejemplo, AGEY, C, CG, "Copiador de la Correspondencia del Gobernador Artazo y Barral con los subdelegados de intendencia y los ayuntamientos de sus respectivas jurisdicciones", vol. 1, exp. 5, f. 9v., 1813). Sin embargo, así como en el pasado hubo arreglos entre subdelegados y alcaldes (por ejemplo, MACHUCA, "El cabildo"), y para el último periodo colonial el subdelegado de Valladolid consta fungir también en la causa de Justicia (por ejemplo, AGEY, $C, J$, "Autos promovidos por el subdelegado y el alcalde de Valladolid contra unos vecinos de dicha villa acusados de ociosos y malentretenidos", vol. 4, exp. 9-A, 1819), la subdelegación de Valladolid termina sumando el juzgado de primera instancia, aunque sea dejando a los alcaldes como interinos. Es el caso de Ignacio Ribas, que reside en Izamal en 1824, para descontento de la Junta Provisional Gubernativa "por las continuas quejas que recibe el gobierno de la conducta judicial y económica de los alcaldes de Valladolid”. La situación, sin embargo, no era excepcional para la última década, según consta: entre otros, AGEY, $C G, A$, "Libro de acuerdos de la Junta Provisional Gubernativa", vol. 1, Despacho 30 de marzo 1824, f. 89; PE, E, "Rosado Roque pidiendo en propiedad el empleo de subdelegado y juez de primera instancia del partido de Valladolid, que desempeña interinamente", vol. 1, exp. 64, 1825.

77 Como fue anunciado anteriormente, dejamos de lado los casos particulares de los presidios del Carmen y Bacalar, así como de Tabasco.

78 AGN, $I$, vol. 54, exp. 1, f. 67. 
las primeras diligencias para instruir una causa, pero también al "modo de proceder brevemente en algunos negocios sin todas las formalidades de un juicio" (cuando no desembocan en un juicio); sumaria es también un "juicio sumario o extraordinario", que constituye sentencia pero por la "vía extraordinaria" por expedita. ${ }^{79}$ En otras palabras, se trata de procedimientos judiciales mínimos,$^{80}$ muy cercanos al proceder gubernativo. En concreto, si el gobernador no ordenaba alguna providencia gubernativa para corregir a un alcalde o simple ciudadano, el subdelegado podía emprender una sumaria contra él. Y viceversa, cuando como juez estaba encargado de emprender averiguaciones acerca de desórdenes, era cuando el subdelegado podía tomar providencias gubernativas de policía.

El punto fundamental es que, al mantenerse los subdelegados como jueces de primera instancia, lo gubernativo y lo judicial quedan separados pero "unido(s)" 11 a nivel de los partidos. Hasta 1837, y de manera muy paulatina, empezaron a desempeñar estas funciones personas distintas. Esta "unión" es una continuidad y constituye la lógica según la cual no se construye un poder ejecutivo nuevo, sino que se sigue garantizando el proceder gubernativo con la justicia, haciendo del subdelegado juez y parte. La figura del subdelegado-juez permite conservar parte de la lógica antigua que sostiene que "manda quien juzga", es decir, que garantiza toda acción gubernativa por la autoridad judicial, lo cual exploraremos con más detalle en el siguiente apartado.

\footnotetext{
79 Véanse, por ejemplo, las definiciones de "sumaria”, “sumario”, “información sumaria”, “juicio sumario o extraordinario”, en EsCRICHE, Diccionario razonado de la legislación civil, respectivamente, pp. 664-665, 313 y 359-360.

80 De hecho, su comisión puede recaer en individuos que no son ni alcaldes ni jueces de primera instancia.

81 “Orden. Nombramiento de jueces de primera instancia”, 25 de septiembre de 1824, Colección de Leyes, t. I, p. 155.
} 
La jurisdicción contenciosa de Hacienda

En el contexto yucateco, el ejemplo más llamativo de cómo la lógica antigua antes descrita permitió que los subdelegados afianzaran su proceder gubernativo es, sin duda, la jurisdicción contenciosa en Hacienda. Como mencionamos anteriormente, el cobro de las contribuciones siguió en manos de los subdelegados. Esto se justificó por dos razones: en primer lugar, porque los subdelegados garantizaban las contribuciones gracias al depósito de fianzas y, en segundo lugar, porque al ser también jueces, eran la instancia encargada de juzgar cualquier resistencia, lo que significa que podían obligar al pago. Frente a los contribuyentes morosos, los alcaldes tenían que recurrir a los subdelegados. Mejor dicho, los subdelegados nunca perdieron la jurisdicción contenciosa de Hacienda precisamente por sus fianzas -como nos lo recuerdan Marta Lorente y Carlos Garriga: juzga quien es responsable- ${ }^{82}$ Por ello, desde 1813, se derogó la jurisdicción contenciosa de intendentes y subdelegados y se traspasó a los jueces de primera instancia, medida que fue confirmada por el constituyente yucateco en $1824 . .^{83}$ Estamos, pues, ante una lógica diametralmente opuesta a la formación de una autoridad ejecutiva que lo es no sólo porque ejecuta, sino porque se juzga a sí misma en sus actuaciones sin que la interrumpa la justicia. Aquí, en cambio, se "asegura" la actuación gubernativa del subdelegado haciendo de él juez y parte.

Ésta es la razón por la cual, ante la urgencia de asegurar el cobro de las contribuciones, los alcaldes de las cabeceras de partido-donde residen los subdelegados-se vieron obstaculizados

82 Garriga y Lorente, Cádiz, cap. 7.

83 "Establecimiento de Juzgados para los negocios contenciosos de la Hacienda pública", 13 de septiembre de 1813, Colección de los decretos, t. IV, p. 247; "Orden. Que a la intendencia corresponde la recaudación de las contribuciones y créditos de la hacienda pública”, 8 de octubre de 1824, Colección de Leyes, pp. 157-158. 
al intentar fungir como interinos en las ausencias de los subdelegados. En 1820, al iniciar el segundo periodo gaditano, "para cortar los desórdenes en que se incurrió en algunos partidos en el año 1813, arrogándose algunos alcaldes constitucionales de los pueblos la jurisdicción contenciosa", el gobernador le recordó al alcalde de Hecelchakán que el decreto del 9 de octubre de 1812 lo prohibía, excepto para las ciudades donde anteriormente los alcaldes "la han ejercido a prevención con los demás jueces ordinarios". ${ }^{84}$ Ahora bien, los alcaldes de las cabeceras, según el decreto del 9 de octubre de 1812, podían fungir como jueces de primera instancia interinos en ausencia de los titulares "exceptuando sin embargo el cobro de contribuciones que en fuerza de su responsabilidad puede [el subdelegado] encargar al que le parezca". 85

Por ejemplo, en 1824, el subdelegado de Izamal fue nombrado diputado. En consecuencia, según el decreto de justicia vigente, entró en funciones como "subdelegado interino" el alcalde de Izamal. Sin embargo, el subdelegado titular dejó la responsabilidad de cobrar las contribuciones no al alcalde, sino a otro individuo en virtud de que se lo permitía la fianza entregada. ${ }^{86} \mathrm{El}$ alcalde presentó su renuncia como subdelegado interino por carecer "de la jurisdicción contenciosa para hacer efectivo el pago de las contribuciones" ${ }^{87}$ El diputado aprovechó para argumentar que era preferible que una sola persona

${ }^{84}$ AGEY, C, CG, "Copiador de la correspondencia del Gobernador con varios ayuntamientos constitucionales de la Provincia”, c. 5, vol. 3, exp. 6, f. 4, 1820; "Decreto. Reglamento", 9 de octubre de 1812, Colección de los decretos, t. III, cap. IV, art. 2, p. 120.

85 Por supuesto, dicha precisión se da con motivo de un conflicto acerca de la legitimidad de un alcalde nombrado subdelegado interino. AGEY, $C, A$, "Relación del subdelegado Pedro Gutiérrez sobre los sucesos ocurridos en la villa al reinstalarse el ayuntamiento constitucional”, vol. 1, exp. 34, f. 4v., 1820.

${ }^{86}$ Sesión del 27 de agosto de 1824, El Primer Congreso, p. 466.

87 "Orden. Nombramiento de jueces de primera instancia”, 25 de septiembre de 1824, Colección de Leyes, t. I, p. 155. 
asumiera ambos cargos, y ésta sería la misma persona a la que previamente había cedido el cobro de las contribuciones. De ahí que el Congreso abriera la posibilidad de nombrar a jueces interinos en casos de "legítima imposibilidad" del titular, como fue el caso del flamante diputado. Esto es una muestra de las dificultades que encontraron los alcaldes para recuperar el espacio contencioso.

No siempre se resolvió así el interinato, ${ }^{88}$ sin embargo lo que importa aquí es lo siguiente: el subdelegado, al ser responsable por la fianza, posee el arma de la jurisdicción contenciosa para obligar a los deudores. Y ello es probablemente lo que reforzó la interpretación del decreto del 9 de octubre de 1812 a favor de los subdelegados para fungir como jueces de primera instancia, es decir, de lo contencioso en general y no sólo en Hacienda. ${ }^{89}$

En contraste, los alcaldes de Mérida y Campeche lograron adquirir "las funciones de subdelegados" gracias a su jurisdicción contenciosa anterior, ${ }^{90}$ y así conservaron no sólo el cobro de la contribución personal, sino la autoridad judicial que aseguraba el cobro. Aquí también se conservó cierta continuidad con el pasado. En este caso, el problema era la irresponsabilidad de los ayuntamientos, debida, sobre todo, a su peso político y a su renovación anual. Por lo tanto, el Congreso Constituyente les

${ }^{88}$ En el caso de Hunucmá, en que J. E. Peña logra conservar la subdelegación a pesar de haber sido suspendido como juez, resalta que los subdelegados tienen interés en mantener la recaudación pues de ella depende la retribución asignada del tanto por ciento, mientras que el cargo de juez no suponía retribución alguna (sesión de 1ㅇ de julio 1824, El Primer Congreso, pp. 415-416).

${ }_{89}$ El decreto gaditano de 9 de octubre de 1812 suprimió las fianzas para los jueces.

90 "Orden. Que el conocimiento de los negocios contenciosos de Hacienda en la plaza de Campeche corresponde a la jurisdicción ordinaria”, 3 de enero de 1824, Colección de Leyes, p. 69. A decir verdad, tuvo que librarse un debate sobre las antiguas facultades del teniente del rey que no podemos desarrollar aquí. 
exigió, en 1824, si bien no una fianza, por lo menos más garantías de su responsabilidad. ${ }^{91}$

Siempre en la misma lógica, cuando el Gobierno logró instalar, en Mérida y Campeche, subdelegados distintos de los alcaldes que habían conservado la jurisdicción contenciosa, pronto el propio subdelegado de Mérida pidió que se le concediera dicha jurisdicción “en los negocios de Hacienda”. Al apoyar la solicitud de este subdelegado, el tesorero general pidió lo mismo para la recién instalada subdelegación de Campeche. ${ }^{92} \mathrm{Y}$ de hecho el Senado puntualizará que a estos subdelegados realmente no se les puede llamar así, sino tan sólo cobradores, precisamente porque la autoridad del cobro no está asegurada por la jurisdicción contenciosa. ${ }^{93}$ En resumen, los casos anteriores nos muestran el intento sostenido por mantener "unidos" lo gubernativo y lo contencioso en una sola figura, con la finalidad de hacer eficiente la acción del Gobierno.

\section{La facultad económico-coactiva}

La estrategia anterior tuvo sus límites. Como recordamos anteriormente, ya para el periodo borbónico lo más expedito y eficaz era actuar gubernativamente, ya fuera por medios "suaves” o "rigurosos”, evitando así los procedimientos judiciales. A partir del periodo gaditano al Gobierno yucateco le urgía, más que nunca, asegurar sus ingresos, para lo cual el procedimiento judicial era largo y engorroso. Sin contar con que, además, para

91 Sesiones del 12 de mayo y 3 de septiembre de 1824, El Primer Congreso, pp. 375 y $476-477$.

92 AGEY, PE, CO, "Libro copiador de la correspondencia reservada de los gobernadores, con la secretaría de estado y sus despachos, y algunas otras autoridades”, vol. 1, 1 exp. 13, s/f, 1828.

93 AGEY, CG, D, “Libro de dictámenes del Senado", vol. 1, fs. 27-30, 1833. Acerca de la función del Senado como consejo de gobierno, véase LoRENTE y Portillo (dirs.), El momento gaditano; Annino, Martínez, Rojas y Solla, en Breña, Cádiz a debate. 
esos años, la dispersión de la población, problema endémico, alcanzó niveles críticos; la población, más que recurrir o postergar cualquier cobro por la vía judicial, simplemente se dispersaba huyendo al monte. De ahí que en Yucatán, desde 1813, por razones de cobro, se encargó a los subdelegados, no sólo a los alcaldes, la misión de "reducir a poblado" a los grupos indígenas dispersos, lo que constituye otra reintroducción de los subdelegados en el ámbito de la policía. ${ }^{94}$

No hemos encontrado suficiente documentación sobre este punto. Las fuentes disponibles permiten documentar la continuidad y profundización del "rigor" que había despuntado en la época colonial tardía: el predominio de la facultad económicocoactiva, es decir, de la posibilidad de exigirles coactivamente a los contribuyentes, así como la capacidad de embargar sus bienes -a reserva de posible reclamo judicial posterior-. Como es sabido, esta facultad constituye, en el ámbito de las contribuciones, el núcleo de la autoridad del Estado para comprimir los derechos de los gobernados sin su consentimiento a fin de asegurar "el interés público". ${ }^{95}$ Desde el primer periodo gaditano, los subdelegados tuvieron el mandato de “ejecutar”, tanto a ayuntamientos que no rendían sus cuentas como a contribuyentes morosos. ${ }^{96} \mathrm{Al}$ refundirse las antiguas contribuciones en contribución personal, el reglamento de 1824 atribuyó la misma facultad económico-coactiva a "los encargados [de los

94 Sesión de 19 de noviembre de 1813, La Diputación Provincial de Yucatán, p. 122, y la orden de 31 de mayo de 1824 ("Artículos adicionales al decreto de 30 de abril último sobre contribución personal”, en Colección de Leyes, t. I, art. 5, p. 120), reiterada el 26 de julio del mismo año al restablecerse la república de indios.

95 Al respecto, centrándose en las leyes expedidas a nivel nacional, LiRA, "La facultad económico-coactiva”, pp. 121-133.

96 Luego se invocará también el decreto "Concediendo a los intendentes ciertas facultades para la cobranza de contribuciones e impuestos)”, 12 de mayo de 1821, en Dublán y Lozano, Legislación mexicana, t. I, pp. 543-544. 
subdelegados] en los pueblos". ${ }^{97}$ Unos días más tarde, se precisó que, en caso de ser insuficientes los bienes de los deudores, se les podría aplicar a "trabajos comunes y labores ordinarias".98

En cambio, en el caso de algún alcalde que "voluntariamente la [cobranza] dificultase", el subdelegado todavía debía preparar una "información sumaria o documental de los hechos para que el gobierno determine el apremio, corrección o castigo". Lo que significa que el procedimiento judicial expedito que comentamos antes se reduce al mínimo para apoyar una decisión en principio gubernativa. En 1825, el último artículo de un decreto sobre el cobro de las obvenciones señalaba que para todas las contribuciones, fueran civiles o religiosas, a la persona "que por seducciones o de cualquier otro modo procurase impedir la recaudación", se le podría aplicar una multa. ${ }^{99} \mathrm{~A}$ los subdelegados de Mérida y Campeche se les otorgó también el equivalente de la facultad económico-coactiva. ${ }^{100} \mathrm{~A}$ partir de 1832, los subdelegados sin jurisdicción contenciosa pudieron arrestar correccionalmente a quienes los insultaran, incluso si habían pagado las contribuciones. ${ }^{101}$

97 "Decreto. Estableciendo y arreglando la contribución personal con cesación de las anteriores", 30 de abril 1824, Colección de Leyes, t. I, art. 12, p. 101. El artículo confirma los apremios del decreto de 12 de mayo de 1821.

98 "Orden. Artículos adicionales al decreto de 30 de abril último sobre contribución personal”, 31 de mayo de 1824, Colección de Leyes, t. I, art. 1, p. 120. $\mathrm{Al}$ año siguiente, en relación con las "contribuciones civiles y religiosas", se precisa la misma facultad para los caciques y justicias con los indígenas, previa una reclamación: "Decreto. Sobre la recaudación de las contribuciones", 26 de noviembre de 1825, Colección de Leyes, t. II, art. 1, p. 33.

99 "Decreto. Sobre el cobro de las obvenciones", 22 de octubre de 1825, Colección de Leyes, t. II, art. 5, p. 20.

100 "Decreto. Facultades a los subdelegados para el cobro de la contribución personal”, 16 de octubre de 1827, Colección de Leyes, t. II, pp. 86-87.

101 "Ley de arreglo del cobro de la contribución personal", 23 de febrero de 1832, Colección de Leyes, t. II, art. 17, p. 205. Este artículo se refiere a todos los subdelegados; sin embargo, remite a dos decretos anteriores que conciernen únicamente a los subdelegados de Mérida y Campeche. A falta de evidencias, 
En efecto, a partir del segundo periodo gaditano se multiplicaron las comunicaciones del Gobierno para que alcaldes y subdelegados procedieran "ejecutivamente" contra deudores de diversas contribuciones. Empero, la propia insistencia es elocuente de su escasa utilidad. Se presentaron diversas dificultades. La milicia cívica se mostró reacia a apoyar a los subdelegados o a los alcaldes, ${ }^{102}$ por lo cual el gobernador envió dragones para apoyar a los subdelegados y, con menor facilidad, a los alcaldes. ${ }^{103}$ En 1824, cuando los subdelegados eran ya los encargados de cobrar la contribución personal, algunos presentaron su renuncia por ser "impracticable", sin importar la facultad económico-coactiva que se les había otorgado. ${ }^{104} \mathrm{La}$ correspondencia disponible revela que justamente en este periodo la Junta Provisional Gubernativa pidió al Congreso Constituyente yucateco el

podemos suponer que en el contexto de 1832, se quisiera dar este medio de apremio a todos los subdelegados (así como, en la misma ley, se endurecieron otros aspectos del cobro). En todo caso, de ser así, ello duró sólo hasta 1833, cuando el nuevo Congreso elaboró una nueva ley de cobro de contribución personal que especifica que el artículo mencionado sólo concierne a los subdelegados sin jurisdicción contenciosa. El comentario del Senado al respecto será analizado más adelante.

102 Por ejemplo, AGEY, PE, CO, "Cuaderno copiador de la correspondencia de los Gobernadores a las autoridades de la subdelegación de Sierra Alta", vol. 1, exp. 10, f. 7v., 1825.

103 Por ejemplo, AGEY, PE, CG, "Copiador de correspondencia de los Gobernadores con las autoridades de los pueblos de Sierra Alta", vol. 1, exp. 3, f. 20, 1822 y f. 59, 1824; AGEY, PE, CO, "Cuaderno copiador de la correspondencia de los Gobernadores a las autoridades de la subdelegación de Sierra Alta", vol. 1, exp. 10, f. 7, 1825; AGEY, CG, A, "Libro de acuerdos de la Junta Provisional Gubernativa”, vol. 1, Despacho del 26 de mayo de 1824, f. 122.

104 AGEY, CG, $A$, "Libro de acuerdos de la Junta Provisional Gubernativa", vol. 1, Despacho del 26 de junio de 1824, f. 135v. No tenemos las explicaciones dadas directamente por los subdelegados. En parte, lo impracticable que resultó el cobro se debe al plazo dado en esa ocasión, así como a las bajas, que no reflejan las matrículas por muertes y dispersión al monte, lo cual explica el restablecimiento de facultades de policía por razones fiscales. Entre otros, véase sesión del 29 de mayo 1824, El Primer Congreso, p. 393. 
restablecimiento de las repúblicas de indios como único medio eficaz para cobrar las contribuciones. Al restablecer les repúblicas con puras funciones recaudatorias, se introdujo la novedad de darles facultades económico-coactivas a los caciques.

No obstante, lo que entonces destaca es que se renovó la antigua forma de cobrar: si bien los caciques ahora podían "ejecutar" a los contribuyentes, como dice uno de ellos, "no se ha atrevido a hacerlo por que no lo aborrezcan y se formen quejas contra él”. ${ }^{105}$

\section{Conciliar para ejecutar}

En efecto, incluso antes de que se extendiera la facultad económico-coactiva a los caciques, frente a la ejecutividad, todos ellos pedían “mediar”, es decir, ser escuchados, si no en justicia, por lo menos de forma extrajudicial. Por ejemplo, en 1823, el alcalde de Xcan señaló que "antes de mediarse el cobro en este Pueblo el Juez de $1^{\mathrm{a}}$ instancia de este partido exige con violencia al comisionado cobratario [sic] dicho ramo". Subrayamos de esta cita que lo que se cuestiona es la falta de mediación, lo que para el alcalde en este caso significa no "entender la presente escasez de grano que generalmente padece esta provincia”. El alcalde, pues, pide tomar en cuenta las circunstancias. La "consulta" del alcalde "para el mejor asiento de las contribuciones"106 es un pedido de composición de intereses en el ámbito puramente gubernativo. Y así, ante el "rigor" de los subdelegados, se

105 AGEY, PE, J, “Sumaria información contra José May, cacique de Pocboc, pueblo del Camino Real Alto, por mal uso de los fondos de algunos ramos”, vol. 1, exp. 9, 1825.

106 BY, "Bernardino Chan y Sixto Poot comunican que el Juez de $1^{\mathrm{a}}$ instancia de su partido exige con violencia el cobro del préstamo forzoso a pesar de la escasez de granos”, XVI-1822-4/4-011, 22 de junio de 1823. En 1824, se determina que "en caso de una epidemia u otro semejante" se podrán rebajar o posponer los enteros de la contribución, Colección de Leyes, t. I, p. 109. 
multiplicaron las solicitudes para tomar en cuenta las epidemias, la escasez de granos y la emigración de la población.

Los propios subdelegados estaban ocupados no tanto en ejecutar, sino en mediar entre los intereses de la Hacienda pública y los de la población. Por ejemplo, aunque el subdelegado se inconforma con la solicitud de la república de Seyé de posponer el cobro de las contribuciones que está haciendo "con fuerza", añade:

Se cobra la contribución conciliando el deber en que me hallo de hacer el recaudo con la actual escasez general y absoluta falta de recursos de los contribuyentes; ésta es tal que apenas llega lo cobrado en todo el partido a doscientos pesos, lo que demostrará a VE que no hay la fuerza supuesta. ${ }^{107}$

En otras palabras, lo que dice el subdelegado es que la ejecución del cobro fue el resultado de una "conciliación". Esto nos indica que los procedimientos "ejecutivos" son desarticulados por una mentalidad jurisdiccional que sigue asociando la ejecución a la audiencia y al consenso del que obedece. Además, que los procedimientos ejecutorios se legitiman por simular procedimientos de composición aunque son, ahora, puramente gubernativos.

Vale la pena aquí volver sobre las multas -otro procedimiento gubernativo coactivo- para puntualizar la doble tensión que se expresa en ellas. Cualquier acto gubernativo es reclamable en justicia, como lo recuerda el jefe superior político en 1814, al imponer una multa a un alcalde: "[deja] al interesado su derecho a salvo para que reclame los perjuicios que haya lugar ante el tribunal designado por la ley"108 y ello no es tema de debate. Lo que se debate es la propia modalidad ejecutoria de la multa. El

107 AGEY, PE, G, "Representación de la república de indígenas de Seyé, pidiendo prórroga para pagar sus impuestos personales, por la escasez de granos", c. 18, vol. 6, exp. 28, 1835.

108 Sesión del 10 de junio de 1814, La Diputación Provincial de Yucatán, p. 294. 
decreto citado del 22 de octubre de 1825 sobre multas a los que se opongan al cobro, las asocia a un "juicio verbal sumarísimo", lo cual remite a la dificultad de concebir la propia ejecutoriedad perse. Unos meses antes se publicó la Constitución, cuyo artículo 190 reza: "la ley determinará los delitos leves y penas correccionales que deben aplicarse sin forma de juicio, y por medio de providencias gubernativas o de policía". ${ }^{109}$ La cuestión no está tanto en evitar recursos judiciales, sino en la audiencia o no de los multados, antes del procedimiento gubernativo-ejecutorio -es decir, en hacerlo más riguroso o no, y desprenderlo de cualquier legitimidad de cuño judicial-aunque se trate de justicia expedita.

Este artículo constitucional no se plasmará claramente en ninguna ley, como se aclara en 1832. En 1826, según la interpretación del Senado, el primer decreto mencionado es el que justifica que le corresponde al alcalde imponer la multa a un indígena que se ha opuesto a la contribución, mientras que el subdelegado sólo puede formar sumaria a los alcaldes que estorben la recaudación. ${ }^{110}$ Otros casos parecen confirmar que el subdelegado no tiene ninguna posibilidad de imponer multas por su propia iniciativa, es decir gubernativamente, sino sólo mediante orden del gobernador por la ley de policía de 1825 a la que nos referimos anteriormente. ${ }^{111} \mathrm{Al}$ contrario, las multas por insultos que pueden imponer los subdelegados-cobradores de Mérida y Campeche son una "compensación” por la falta de la jurisdicción contenciosa de los subdelegados-jueces, puesto que, como aclara el Senado, los insultos a un juez merecen penas más graves ya tipificadas en las leyes. ${ }^{112}$

109 Las constituciones, p. 322.

110 AGEY, CG, $A$, "Libro de acuerdos del Excelentísimo Senado de Yucatán”, vol. 9, f. 21, 1826.

111 Por ejemplo, AGEY, CG, $A$, “Libro de acuerdos del Excelentísimo Senado de Yucatán”, vol. 9, f. 38v., 1827.

112 AGEY, CG, D, “Libro de dictámenes del Senado”, vol. 1, fs. 30-30v., 1833. Se publica la nueva ley tomando en cuenta esta aclaración: “Ley. Que arregla el 
En suma, aunque no faltó seguramente una buena dosis de casuística en el asunto, seguía predominando la idea de la mayor autoridad de lo judicial. Y dicha preeminencia llega hasta obstruir la concepción de una multa puramente gubernativa y, por ende, la atribución a los subdelegados de dichas multas gubernativas. En cambio, los planteamientos que se hicieron en el Senado en 1832 muestran que, a partir de las normas antes mencionadas, también cabía individualizar el carácter estrictamente ejecutorio de las multas. En esa ocasión (que no atañe directamente a los subdelegados, pero menciona a los jueces de Mérida -que sí tienen la jurisdicción contenciosa-, los cuales imponen multas sin ninguna forma de juicio desde 1824) se estableció que, por lo menos desde 1824, nunca "ha estado prohibida la aplicación de penas correccionales sin forma de juicio". ${ }^{113}$ Cabe mencionar desde ahora que esta interpretación, como otras medidas del mismo año que profundizan la ejecutoriedad, es de filiación centralista, la que desde 1829 trató de afianzar la autoridad gubernativa, como veremos más adelante.

\section{La responsabilidad de los subdelegados}

En vista de lo anterior, tenemos, por una parte, la tendencia a ejecutar y, por la otra, que ésta genera formas de audiencia extrajudiciales. Y es que, de nuevo, ser juez y parte no redunda en una autoridad ejecutiva. Los subdelegados-jueces no dejan de ser personalmente responsables de sus procedimientos y de las cantidades que cobran. Es decir, no actúan como autoridad pública que se impone a los particulares, sino como lo que son: mediadores entre diversas instancias.

cobro de la contribución personal”, 23 de noviembre de 1833, Aznar Pérez, Colección de leyes, art. 14, p. 148.

113 AGEY, CG, D, “Libro de dictámenes del Senado”, vol. 1, fs. 9v.-10, 1832. 
Recordemos la doble dirección que estaba tomando la responsabilidad de los subdelegados del periodo borbónico. Por un lado, eran enjuiciables por cualquier interés lesionado -aunque siempre protegidos por la jurisdicción real-; por otro, los intereses "superiores" de la Hacienda real empezaban a imponerse mediante la revisión más estricta de las cuentas de los subdelegados y de sus fianzas. En el periodo gaditano en Yucatán se retomó la primera de estas tendencias, lo que ha sido puesto de relieve para el ámbito hispánico en general: se "reformuló" el juicio de residencia mediante el enjuiciamiento, iniciado por cualquier individuo, por infracciones a la Constitución o a la ley. ${ }^{114}$ Es decir, que no se puso en planta un autocontrol normado de los procedimientos gubernativos en función de los intereses públicos, sino que dicho control se encomendó al reclamo de los demás intereses que pudieran sentirse lesionados.

Lo que sí se mantuvo fue la protección a los intereses de la "Hacienda pública" por medio del antiguo sistema de fianzas. Al parecer, lo que predominó en el control de estos funcionarios fue la revisión de sus cuentas, poniendo coto al criterio político. ${ }^{115}$ Pero, al tratarse, como antes, de una responsabilidad personal, y no estando garantizadas sus actuaciones por la justicia superior del rey, los subdelegados quedaron entre dos fuegos.

\footnotetext{
114 Lorente y Portillo (dirs.), El momento gaditano, cap. 9.

115 El seguimiento continuado de las causas a los subdelegados ha resultado imposible. Sin embargo, parece que los casos de enjuiciamiento (pedidos por el tesorero general) y de suspensión (decididos por el gobernador) por no rendir cuentas o por malversación privan sobre otras infracciones denunciadas por particulares o alcaldes. Respecto a las acusaciones que les son hechas en cuanto jueces, hay que señalar que estuvo a debate si su enjuiciamiento tenía que pasar por el Congreso y el Senado o si dependía directamente del Tribunal. Véase, entre otros, sesión del 4 de octubre de 1823, El Primer Congreso, p. 76; "Decreto. Organización de los tribunales del Estado", 24 de noviembre de 1823, Colección de Leyes, art. 9, p. 47; AGEY, CG, S, "Libro de sesiones del Congreso", vol. 5, f. 140v., 1832.
} 
El constituyente yucateco de 1824 estableció una protección mínima a todos los "funcionarios públicos", muy relevante si comparamos la completa desprotección de los mismos en otras regiones. En el marco de la Constitución de 1825, toda acusación judicial a los "funcionarios públicos" pasa por el Congreso, quien decide si ha lugar a formación de causa, causa que, en caso afirmativo, se encarga al Senado. Esta protección rige claramente para los subdelegados de Hacienda, es decir, que fue un intento, si no de garantizar, por lo menos de proteger el ámbito gubernativo. ${ }^{116}$ Sin embargo, el control y la protección de que gozaron los subdelegados siguieron siendo de naturaleza eminentemente política -de hecho, este tipo de control y protección será asumido por la Constitución de 1841 como “juicio político" y no como juicio administrativo, justamente porque no lo es.

De nuevo, entonces, la centralidad del control de la población con miras impositivas produjo la unión de los cargos como medio para la jerarquización a nivel de los partidos, así como la multiplicación de los procedimientos ejecutorios en favor tanto de subdelegados como de otros cobradores y autoridades encargadas de controlar a la población. Además, se otorgó una protección mínima en estos procedimientos gubernativos. No obstante, las propias herramientas de control y de protección de las actuaciones de los subdelegados no favorecieron el control ni la supremacía de sus actos en cuanto actos públicos. Así, las herramientas coactivas diseñadas para expandir el ámbito gubernativo más bien favorecieron los arreglos extrajudiciales

\footnotetext{
116 La importancia de dicha protección la recalca el hecho de que se les otorgue a los subdelegados-cobradores también en cuanto al uso del procedimiento ejecutivo ("Decreto. Se autoriza a los subdelegados para proceder contra los deudores de contribuciones; y se nombra subdelegado para Bacalar", 27 de septiembre de 1828, Colección de Leyes, t. II, arts. 1-2, p. 131). Por supuesto, el Gobierno comienza por imponer multas a los subdelegados, antes de llevarlos a juicio vía el tesorero general.
} 
-es decir, discrecionales- a fin de evitar el enjuiciamiento de la responsabilidad personal.

Recapitulando, con la división de poderes, el nuevo "poder ejecutivo" se enfrentó a su dispersión debido a la municipalización. La conservación del subdelegado como juez de primera instancia no sólo acotó de tajo el poder de los alcaldes constitucionales, sino que permitió al Gobierno recuperar ámbitos gubernativos cruciales, como el cobro de impuestos. En otras palabras, la antigua lógica jurisdiccional se puso al servicio de la concentración de la coacción legítima. Los subdelegados constituyen, así, una estrategia de cuño tradicional para concentrar el poder por parte de un Gobierno que no ha asentado su soberanía y que no trata de asentarla: sus únicas herramientas gubernativas, los subdelegados, lejos de ejecutar simple y llanamente sus órdenes, son eficaces por ser jueces. Lo que significa que tienen la posibilidad de negociar, judicial o extrajudicialmente, con los gobernados la ejecución de sus órdenes.

Como veremos a continuación, los jefes políticos que surgieron unos años más tarde se configuraron como una instancia abocada justamente a la negociación extrajudicial. Con ellos no se concretó una nueva autoridad ejecutiva, distinta y autónoma de la judicial, sino que se precisó y refinó la praxis gubernativa, y se expandió el procedimiento gubernativo, marginando cada vez más los métodos jurisdiccionales, pero remitiendo siempre a ellos para legitimarse.

EL JEFE POLÍTICO: EL DESARROLLO DE LO GUBERNATIVO DISCRECIONAL Y CONSENSUAL

\section{¿Una nueva autoridad? Primeros planteamientos}

El establecimiento de jefes políticos como delegados del Gobierno parece dar paso a la concreción de un verdadero poder 
ejecutivo. Veamos por qué, poniendo especial atención en las distintas ocasiones en que se intentó su establecimiento, que se consolidó a partir de 1834.

En 1820 por primera vez se planteó en Yucatán establecer los "jefes políticos subalternos" contemplados por la legislación gaditana. En ese entonces, la propuesta se formuló de la siguiente manera:

Estas autoridades [ayuntamientos y alcaldes constitucionales] están por una lamentable ignorancia [...] distantes de la verdadera y discreta inteligencia de sus peculiares atribuciones e incapaces por sí de dar cumplida ejecución a los proyectos y reglas constitucionales. Esta triste circunstancia obliga al gobierno superior a descender con precaución a las más minuciosas y prolijas explicaciones [...] acaso convendría tener en jefes políticos subalternos cooperadores eficaces que acelerando el impulso de los conatos y la ejecución de las providencias superiores explicase[n] uniforme y simultáneamente su bondad enérgica y consiguientes efectos al régimen constitucional. ${ }^{117}$

En la cita, con lenguaje de cuño ilustrado que remite a explicaciones más que a órdenes imperativas, la propuesta de establecer delegados del Gobierno en los partidos no deja de recordarnos la concepción prefectoral: la uniformidad que cobraría la ejecución de las "providencias superiores", dos veces asociada a su rapidez. Es decir, se trata de la monopolización de la autoridad, sin las dilaciones (típicamente jurisdiccionales) que la hacen menguar. ${ }^{118}$ De hecho, en la propia propuesta, al precisar el campo de

117 BY, "Libro de correspondencia de la Diputación Provincial de 1813 a 1823”, LMEP-106, fs. 122-123v., 1820.

118 Recuérdese la célebre presentación de Chaptal, miembro del Consejo de Estado que elaboró la ley de 28 Pluvioso del año 8 (1800): con los prefectos y subprefectos, se creaba "una cadena de ejecución [que] desciende sin interrupción del ministro hasta el administrado, y transmite la ley y las órdenes del 
acción concernido, se "recuerda" la subordinación que se trata de obtener de los ayuntamientos, la jerarquización:

[Las] atenciones de gobierno y policía y las materias [...] gubernativa y económica, que influye más inmediata directamente y eficazmente en la libertad, seguridad y prosperidad de los pueblos, reside exclusivamente en el jefe superior y bajo su inmediata subordinación en los ayuntamientos y alcaldes constitucionales. ${ }^{119}$

Para entonces, la diputación provincial alegó que se necesitaba una "experiencia lenta y reflexiva” y que "sería sin prudencia alterar el actual sistema, dando lugar a innovaciones”. Detrás de esta negativa se encontraba la rivalidad política entre el Gobierno capitalino y el puerto de Campeche. Con todo, confirma el intento de estirar lo más posible las antiguas formas de gobierno con las reformulaciones y limitaciones que apuntamos anteriormente. ${ }^{120}$

El establecimiento de jefes políticos por los centralistas pronunciados a finales de 1829 parece remitir a la misma idea de un solo foco de mando vertical, con resabios antiguos: se trata de asegurar "la buena circulación de las órdenes superiores", circulación que irá de arriba hacia abajo. Por primera vez se establece que en aquellos pueblos donde desaparezcan las juntas

gobierno hasta las últimas ramificaciones del orden social con la rapidez del fluido eléctrico" (traducción de la autora). La misma imagen la retoma José María Luis Mora comentando el establecimiento de los jefes políticos en el Estado de México en 1825. Brondino, "L'implantation", pp. 295-307.

119 BY, "Libro de correspondencia de la Diputación Provincial de 1813 a 1823”, LMEP-106, f. 122, 1820.

120 De hecho, aprovechando la legislación gaditana que permitía establecer jefes políticos subalternos en los puertos de mar, Campeche ya tenía "jefe político subalterno", sin embargo, se había neutralizado dicho establecimiento al encargar la jefatura política al alcalde 1 (Sesión del 14 de febrero de 1814, La Diputación Provincial de Yucatán, p. 189). De ahí que, en noviembre de 1820, cuando se planteó establecer jefaturas políticas, se puntualizara que en Campeche no había ninguna. 
municipales y los alcaldes, serán reemplazados por jueces de paz que a su vez "dependerán” de los jefes políticos en lo no judicial. Para la elección de dichos jueces, los jefes políticos no sólo informan sino que elaboran las ternas que enviarán al Gobierno. ${ }^{121}$ La poca información conservada en los archivos remite a un antecedente de aspectos jerarquizantes de las jefaturas políticas posteriores, ${ }^{122}$ pero no nos permite analizar debidamente el impacto de este primer establecimiento. Sólo podemos señalar que, aun cuando se cancelaron estas efímeras jefaturas, se mantuvieron algunas de sus prácticas aunque sea de manera no sistemática, como por ejemplo la circulación de las leyes y las órdenes por el conducto de los subdelegados-jueces, anticipando así los rasgos de la jefatura política que en efecto se implementará más adelante. ${ }^{123}$

Pese a las carencias de información, hay que mencionar por lo menos un punto importante de las jefaturas políticas de 1829. Algunos autores han insistido en la lógica antigua de acumulación de funciones, ${ }^{124}$ pues en esta ocasión -el pronunciamiento centralista liderado por José Segundo Carvajal- el jefe del ejecutivo era también el jefe militar, suprimiéndose el Congreso. El carácter militar del jefe de gobierno y de varios jefes políticos viene a reforzar el proceder ejecutorio o el recurso a la "vía reservada”. ${ }^{125}$ Empero, José Segundo Carvajal insistió en su

121 “Circular del gobierno militar, político y de hacienda de Yucatán”, 21 de noviembre 1829, Diario histórico, s. p.

122 Y que se insertan en un proyecto más amplio del que subrayamos la intención de establecer "instituciones de menos complicación", lo cual leemos como uniformización jerarquizante. Impugnación, p. 6.

${ }^{123} \mathrm{Y}$ así lo considera asentado el Senado en su dictamen que no tiene por objeto discutir este punto: AGEY, CG, D, "Libro de dictámenes del Senado", vol. 1, f. 104, 1833.

${ }^{124}$ Por ejemplo, Campos García, “Que los yucatecos”, p. 124.

125 El Senado comentará que "es una verdad generalmente reconocida que la reunión del mando político al militar robustece y de más expedito el ejercicio de la autoridad pública, así como dividido la debilita y en ciertos casos lo 
responsabilidad personal e impulsó la reelaboración del juicio político. ${ }^{126}$ Por lo que respecta a los jefes políticos, éstos parecen quedar perfectamente desprotegidos -a no ser que, de manera circunstancial, gozaran de fuero militar-. ${ }^{127}$ Es decir que, puesto que la jerarquización y la ejecutoriedad ya no se sustentan en la antigua equidad real, cuanto más se refuerza el gobierno ejecutorio, más necesaria se vuelve su legitimación por medio de la enjuiciabilidad. ${ }^{128}$

\section{Jerarquización y tutela gubernativa}

Tras este primer experimento, que duró menos de dos años, los siguientes intentos de establecer jefes políticos se dieron en 1832

entorpece y la constituye menos ejecutiva" (AGEY, CG, C, "Copiador de la correspondencia del Senado yucateco con el Excmo. Gobierno", vol. 3, ff. 14-14v., 1832). A modo de ejemplo de los efectos de esta "reunión" y del uso de la "vía reservada", mencionemos el procedimiento para con los vagos. El "Reglamento provisional para el interior gobierno de los pueblos de Yucatán" de 1829 mantiene la formación de sumaria a todo sospechoso de ser vago, y endurece la condena al servicio de línea permanente por cinco años (Diario bistórico, s. p.). Ahora bien, consta el recurso a la "vía reservada" para la aprehensión de "individuos tenidos por vagos", por ejemplo, en una colaboración entre los alcaldes de Mérida y el comandante de armas del cuartel y jefe político subalterno de Mérida: AGEY, PE, CO, "Correspondencia de los juzgados de los alcaldes y subdelegados con el jefe político superior y comandante de las armas del cuartel de Mérida”, vol. 2, exp. 9, s/f, 1831.

126 Insistiendo en la independencia del Gran Jurado y su procedencia municipal. Para un recuento pormenorizado de este punto, véase Flores EsCALANTE, "El primer experimento", pp. 66-67.

127 Según Flores Escalante, Entre el centralismo, p. 40, la mayoría fueron militares; en las fuentes disponibles que pudimos consultar, nos ha sido imposible precisar este dato en sentido positivo o negativo.

128 Además, los centralistas llegaron al poder por medio de un pronunciamiento. No pudiendo comentar aquí otros aspectos importantes, señalamos que habría que profundizar en este capítulo esencial del establecimiento de los jefes políticos analizando el conjunto del proyecto y del legado políticoinstitucional del centralismo yucateco que todavía queda por revisarse. En este sentido, véase QuEZADA, "Formas de gobierno”, pp. 245-257. 
y 1834, de nuevo por grupos de filiación centralista. El primer decreto no tuvo tiempo de ser publicado, pues se dio un nuevo pronunciamiento. Pero el de 1834 es prácticamente idéntico al primero y definió el perfil del jefe político para el resto del siglo. Comienza anunciando la verticalización de la autoridad y el inicio de su monopolización. En efecto, los jefes políticos se establecen "para la más expedita dirección de los negocios y régimen interior de los pueblos del estado". ${ }^{129}$ Además, aunque los jefes políticos sean todavía los subdelegados y jueces de primera instancia, se precisa su subordinación al "gobierno" que ya no encarna un jefe superior político ni un militar pronunciado, sino el gobernador, ahora electo por sufragio indirecto. ${ }^{130} \mathrm{Se}$ añade también que serán los jefes políticos, y no los alcaldes de las cabeceras de partido, los encargados de circular las leyes, es decir, que encabezan la puesta en planta de la ley, cosa que los subdelegados hicieron sólo por suplencia antes de 1829. La precisión del último artículo de que "harán cumplir las órdenes que éste [el gobierno] comunique" remite a una autoridad exclusiva. Todo lo cual parece acompañar lógicamente al hecho de que

129 Las cursivas son nuestras. "Decreto. Estableciendo jefes políticos para el gobierno interior de los partidos”, 20 de noviembre de 1834, Aznar Pérez, Colección de leyes, t. I, art. 1, p. 207.

$130 \mathrm{El}$ jefe político todavía no es hechura del gobernador, pues éste elige a cada jefe político de una terna propuesta por el Senado, a partir de las candidaturas que se presenten. Además, en este decreto el cargo queda como un anexo de atribuciones del subdelegado pues no se individualiza respecto a él en términos de condiciones de empleo. Efectivamente, la duración de la jefatura no se especifica y así será hasta la legislación nacional de 1837. Por ende, sigue dependiendo de la duración de la subdelegación, fijada en cuatro años en 1829 (aunque desde la época gaditana, la inestabilidad política interfiere en la duración prefijada y en la selección de sujetos “aptos”). Tampoco se le asigna sueldo, excepto a las jefaturas de Mérida y Campeche. En este sentido, los jefes políticos más "sujetos" al mando político-gubernativo del gobernador son los de Mérida y Campeche que, por lo visto anteriormente, son distintos de los subdelegados-cobradores y de los jueces, y que además perciben sueldo. AGN, Gs/s, c. 435, exp. 12, f. 1v., 1835. 
los subdelegados, ahora jefes políticos, se ocupen (o vuelvan a ocuparse, como en el periodo borbónico) de todo el ámbito "gubernativo, económico y de policía" de las municipalidades, dándoles "por derecho la autoridad que han ejercido de hecho hace algún tiempo", ${ }^{131}$ según lo expusieron los diputados de 1832 y como estaba apuntando desde antes de 1829. En suma, lo que parece surgir aquí es una autoridad delegada del poder ejecutivo.

Pese a lo anterior, tras el primer artículo que parece trazar la verticalidad del mando y que resume el accionar del jefe político en todos los ámbitos, éstos se desglosan bajo otra modalidad. Toda la esfera económico-gubernativa-policial de los ayuntamientos concierne al jefe político en cuanto tiene que "cuidar [...] el buen orden, de la seguridad y las personas y bienes de sus habitantes y de la observación de las leyes" (art. 1); "velar" por la "observancia de las leyes de policía, salubridad y comodidad" y "procurar cumplan los ayuntamientos con sus atribuciones" (art. 3). Así, aunque se destaca la subordinación al Gobierno, hacia abajo se reintroduce el espíritu de la tutela de antiguo cuño que viene a sobreponerse a los ayuntamientos en las tareas de las que ellos siguen encargados. Lo que significa que estos jefes políticos no vienen, como subordinados del gobernador, a dirigir por sí mismos los partidos, sino que vienen a disciplinar a las autoridades ya existentes. Así parece confirmarlo el secretario general de Gobierno en 1841 al insistir en que "la autoridad toda de los jefes políticos, se contrae a procurar esto o lo otro, a vigilar, a cuidar, a celar, a cooperar para esto o aquello", ${ }^{132}$ afirmación sobre la que volveremos. Por muy agresivo que pueda

131 AGEY, CG, S, “Libro de sesiones del Congreso”, vol. 5, f. 130v., 1832. Lo mismo se declara con motivo del primer establecimiento de 1829. La excepción es, de nuevo, Mérida y Campeche, que sólo tienen subdelegados-cobradores y alcaldes: de hecho, la propuesta de establecer jefes políticos se dirige sobre todo a estas dos ciudades.

132 Memoria, p. 4. 
parecer este funcionamiento, por ejemplo con la participación del jefe político en las sesiones de los ayuntamientos (art. 4), ${ }^{133}$ lo que sobresale es que el establecimiento de lo que parece ser un inicio de aparato administrativo, por lo menos a nivel del partido, no va aparejado con un espíritu administrativo ejecutorio. No se abre un espacio administrativo de ejecución de las leyes a cargo de un nuevo funcionario, sino que se expande el espacio de lo gubernativo para la puesta en planta de las leyes vía la tutela gubernativa ${ }^{134}$ de las autoridades municipales y de la población en general.

\section{El fortalecimiento del gobierno ejecutorio}

Por otra parte, el mencionado decreto de 1834 viene a marcar el fortalecimiento del gobierno ejecutorio que parece prolongar lo que vimos desde por lo menos el segundo periodo gaditano. Mencionamos ya la facultad económico-coactiva de los subdelegados (que en el ámbito municipal sólo eran el medio del Gobierno para hacer efectivas multas que ellos no decidían); ahora, además, los jefes políticos pueden imponer las penas de policía y, es más, multas a quienes los desobedezcan o les falten al respeto-posibilidad que destaca por su amplia discrecionalidad (art. 2)-. Ambas herramientas coactivas están en poder del mismo individuo, puesto que los nuevos jefes políticos serán, por lo menos en 1834, los propios subdelegados de Hacienda. Estas

133 En fuentes consta que los jefes políticos de estos primeros años sí aprovecharon dicha atribución. Sin embargo, hay que puntualizar que ello no equivale a una dirección monocrática, pues se les insertaba en un órgano colegiado.

134 El contraste con el caso-modelo prefectoral francés es esclarecedor: el prefecto "administra solo el departamento", teniendo los ayuntamientos un papel consultivo. La "tutela administrativa” deja a los ayuntamientos "asimilados a menores de edad”: BARON DE GÉRANDO, Institutes, p. 172 y siguientes. En cambio, en Yucatán, como en el resto del país, las repetidas quejas acerca de la ignorancia o juventud de los integrantes de los ayuntamientos no generan un derecho de "tutela administrativa". 
multas son, como explicitaron los contemporáneos, "gubernativas”, es decir, que se ejecutan en el acto, sin mediar audiencia de los multados.

Destaquemos, además, que la facultad de imponer multas no suple la falta de jurisdicción, como fue el caso de los subdelegados de Mérida y Campeche, y tampoco queda limitada a los subdelegados-jueces. Ahora, a las penas relacionadas con un procedimiento judicial, se añaden aquellas en las que incurren los que falten al respeto del juez de primera instancia: penas menos graves, pero ejecutorias. La ejecutoriedad por parte de este agente del Gobierno se afirma también en el hecho de que ya no está limitado, como juez de primera instancia, a dar precedencia a los alcaldes en las penas más leves, como sí se interpretó anteriormente. Aquí también, por lo tanto, los jefes políticos se sobreponen y duplican a los alcaldes. ${ }^{135}$

En resumen, lo que parecía delinearse como una nueva autoridad ejecutiva para encabezar los partidos se definió, en realidad, por su proceder gubernativo, la multiplicación de los procedimientos ejecutorios y de los ámbitos de acción. No se trató, en consecuencia, de una modificación en la concepción de la autoridad. Ciertamente, dichos procedimientos apoyaron la jerarquización, pero por sí solos resultaron inútiles, como nos lo indica su ineficacia para el cobro de las contribuciones mencionada anteriormente. El mando gubernativo siguió sin ser imperativo, justamente porque su lógica siguió siendo la acumulación de funciones: los subdelegados-jueces asumieron y respaldaron las jefaturas políticas y siguieron siendo personalmente responsables por lo menos ante el Senado. La continuidad de esta concepción de la autoridad, a pesar de las nuevas facultades que fue adquiriendo, se expresa en la diversidad de fórmulas que los jefes políticos usaron para referirse a sí mismos: algunos, tratando de asuntos penales, se llamaron

${ }^{135}$ Lo que no dejará de generar conflictos de autoridad entre los dos. 
"jefe(s) del partido", mientras que otros prefirieron "jueces políticos", manifestando así que ellos mismos solían no disociar sus funciones. ${ }^{136}$

Esta versión del jefe político es fruto de lo que es considerado el experimento centralista yucateco, que se adelantó al establecimiento del centralismo en la esfera nacional. ${ }^{137}$ En este ámbito, las normas centralistas muestran un esfuerzo mayor por distinguir, individualizar y darle cierta autonomía al procedimiento gubernativo. Entre otras cosas, el jefe político adquirió más procedimientos gubernativos, ${ }^{138}$ algunos de los cuales comenzaron a no poder ser objetados sino ante el gobernador, "sin ulterior recurso". ${ }^{139}$ En lo concerniente a las multas y sus equivalentes en obras públicas o arresto, en el ámbito nacional se repite básicamente lo estipulado en el decreto yucateco de 1834, pero se explicita que se imponen "gubernativamente", matizando únicamente la posibilidad de oír a los multados "sumaria y

136 En la correspondencia oficial, muchas veces los nombres de los tres cargos son intercambiables, predominando la de subdelegado (claramente usado también como sinónimo de juez de primera instancia), aunque es la de jefe político la que va privando rápidamente, por lo menos a partir de 1835 .

137 No podemos entrar aquí en la consideración de las jefaturas políticas existentes en otros estados y que sin duda sirvieron de ejemplo para la elaboración de la yucateca.

138 Por ejemplo, el procedimiento gubernativo acerca de la calificación y penalización de vagos fue reiteradamente rechazado, al menos en principio, hasta entonces exigiendo siempre por lo menos una sumaria (véase la nota 79). Ahora no sólo lo encarga el Gobierno nacional a los jefes políticos, mientras que los alcaldes sólo pueden "reprehender" a los vagos. Por lo menos en una ocasión, el Gobierno yucateco excluye explícitamente el auxilio de los ayuntamientos y preconiza el mero criterio de la notoriedad para la calificación. "Reglamento provisional para el gobierno interior de los Departamentos", 20 de marzo de 1837, en Dublán y Lozano, Legislación, t. III, arts. 67 y 171, pp. 330 y 336, y AGEY, $P E, C O$, "Correspondencia de la prefectura del distrito de Valladolid con el Gobernador del Departamento", vol. 7, exp. 4, s/f., 1838.

139 Por ejemplo, Dublán y Lozano, Legislación, t. III, art. 67, p. 330. 
verbalmente, en caso que lo pidan". ${ }^{140}$ Pese al aumento de su poder en términos generales, los ahora prefectos-subdelegados perdieron la protección contra el enjuiciamiento de su responsabilidad personal.

En todo caso, lo que destaca en el Yucatán de esos años es la rapidez con que los jefes políticos se convirtieron en mediadores gubernativos: aun presentándose como ejecutores de órdenes superiores, siempre podían mediar entre éstas y los intereses de los pueblos, como ya lo hacían los subdelegados. ${ }^{141}$

140 Dublán y Lozano, Legislación, t. III, art. 64, p. 329.

141 La legislación centralista nacional no promueve sólo lo ejecutoriogubernativo, sino también lo ejecutivo-legalista, y de ello se hace eco la Junta Departamental yucateca en 1837. Sin embargo, respecto a las multas, por ejemplo, los ahora denominados prefectos y subprefectos no olvidan que la coacción va aparejada de otros caminos, como se desprende de un correo del subprefecto de Motul: "los ciudadanos han terminado sus querellas particulares amistosamente o las siguen por los trámites legales, obedenciarán [sic] las autoridades legítimas. Así es que no han dado lugar a que aquéllas recurran a las multas de la ley para castigarlos". AGEY, PE, CO, "Correspondencia del Prefecto del Distrito de Izamal”, vol. 7, exp. 3, s/f, 1838. Por su parte, el prefecto de Valladolid asegura que ejecutará las órdenes acerca de los vagos, pero señala sus inconvenientes y alude a otros procedimientos, AGEY, PE, $\mathrm{CO}$, "Correspondencia de la prefectura del distrito de Valladolid con el Gobernador del Departamento”, vol. 7, exp. 8, s/f, 1838. Respecto a los vagos, se ha señalado la presión del contingente de sangre, CAmpos GARcía, "Que los yucatecos”, pp. 179-186. Para nuestro tema, hay que precisar que los tímidos intentos de mediar como el del prefecto de Valladolid, se acentúan cuando comienza a tambalearse el gobierno centralista de Pedro Marcial Guerra y se dan entre otras estrategias para no cumplir las órdenes. Hay que decir también que la misma actitud despuntaba ya durante el precoz centralismo yucateco. El hecho de que para el primer establecimiento de los jefes políticos, éstos se convirtieran en conducto de comunicación ordinario entre las autoridades de los pueblos y el gobierno, sin duda jerarquiza y, a la vez, expresa y consolida su papel de mediadores gubernativos. AGEY, $M, T$, c. 1, vol. 1, exp. 5, fs. 2v.-3, 1830. Por otro lado, no es menos significativo que este conducto nunca termine de imponerse como exclusivo y, por lo demás, deje de ser el acostumbrado en cuanto a las proclamas de adhesión política. 


\section{Coacción y conciliación}

Una paradoja permite adentrarnos en esta concepción de la autoridad gubernativa, por contraste con la ejecutiva. Unos años más tarde, Yucatán vuelve a abrazar el federalismo y estrena su Constitución del 31 de marzo de 1841, revestida de nuevas leyes de justicia y de gobierno interior de los pueblos que se expidieron el mismo día. Esta nueva normativa no sólo confirmó la existencia de los jefes políticos, sino que introdujo modificaciones que van en el sentido de la jerarquización, tanto del gobernador hacia el jefe político como de éste hacia abajo. ${ }^{142}$ Pero los jefes políticos perdieron la facultad de imponer multas en los términos del decreto yucateco de 1834 y de la ley nacional de 1837. ${ }^{143}$ Ello les planteó problemas muy concretos. El jefe político subalterno de Motul, por ejemplo, no logró remitir todas las "relaciones de labranzas" porque, al igual que en el periodo gaditano, las autoridades de los pueblos "no acertaron en comprender cómo se ha de hacer" o no las entregaron "por suma apatía". Ahora -se lamenta este jefe político subalterno"los jefes políticos carecen de coacción". Pese a que amenazó a los morosos con multas, es consciente de que no puede concretar su amenaza. ${ }^{144}$ Unos meses más tarde, el secretario general del

${ }^{142}$ Incluso se inserta la figura del jefe político en la Constitución que, por primera vez, incluye un apartado sobre la "Administración departamental", novedades que remiten justamente a la idea de verticalización y unificación de una autoridad administrativa. Las constituciones, p. 447.

143 Tendríamos que añadir que cuando se cancela la ley de 1837, se restablecen de manera temporal (presumiblemente en espera de la nueva Constitución y de la nueva ley para el gobierno interior de los pueblos) los capítulos 3 y 5 del reglamento de policía de 1825, es decir, las multas a alcaldes y particulares, lo cual confirma su importancia como herramienta coactiva. En cambio, la nueva ley para el gobierno interior de los pueblos explicita la cancelación de multas y prisiones. "Ley. Reglamento para el gobierno interior de los pueblos", 31 de marzo de 1841, Aznar Pérez, Colección de leyes, t. I, art. 77, p. 108.

144 AGEY, PE, CO, "Correspondencia del Jefe Superior Político del Departamento de Izamal con el Gobernador del Estado”, vol. 2, exp. 42, s/f, 1841. 
Gobierno será contundente; según él, mientras los alcaldes de los ayuntamientos posean facultades claras de coacción:

La autoridad toda de los jefes políticos, se contrae a procurar esto o lo otro, a vigilar, a cuidar, a celar, a cooperar, para esto o aquello, y no se les determina el poder que deben ejercer para hacerse respetar y obedecer. Invístaseles con la expresión necesaria del que corresponde a su autoridad: facúlteseles para imponer multas y arrestos proporcionados a los que los desobedezcan, y de esta manera su autoridad será efectiva y tendrán el prestigio de que absolutamente carecen. ${ }^{145}$

El secretario general apunta al vacío de poder de los jefes políticos: su autoridad, que sólo consiste en la tutela, huérfana de la garantía de equidad real, es muestra de que no ha surgido un poder nuevo que se distinga del proceder gubernativo. Sólo los ayuntamientos han logrado potenciar su proceder gubernativo gracias a la representación electiva. Y, al mismo tiempo, la definición de este poder se lograría, según el secretario general, con la devolución a los jefes políticos de un procedimiento ejecutorio. Confirma, pues, que la concepción del gobierno "ejecutivo" no ha cambiado.

$\mathrm{Al}$ mismo tiempo, la ausencia de concepción de una nueva autoridad sí modificó las prácticas de gobierno. De alguna manera, lo ejecutorio -en este caso, las multas más discrecionales y los arrestos- hace las veces de una nueva autoridad. Se modifica el gobierno de cuño jurisdiccional porque, aunque no se concibe un poder ejecutivo que pueda comprimir los derechos de los gobernados sin su consentimiento en nombre del interés público, sino tan sólo un proceder gubernativo antesala del judicial, se sigue buscando la concentración del poder. Por lo tanto, se acudió a la multiplicación de las herramientas coactivas:

145 Memoria, p. 4. 
pese a no tener la fuerza de cosa juzgada, su número y discrecionalidad lograron imponer las órdenes gubernativas con una contundencia avasalladora. De hecho, las multas suprimidas en 1841 se restablecieron en $1842 \mathrm{y}$, definitivamente, en 1843. ${ }^{146}$

La multiplicación de las herramientas coactivas se volvió más necesaria conforme el cargo de jefe político se fue separando del de juez, deshaciendo con ello la solución que hasta entonces se había encontrado para contener la separación de poderes, por lo menos “en primera instancia”. En efecto, si el jefe de la revolución federalista empezó nombrando nuevos subdelegadosjueces en 1840, la nueva normativa de 1841 estableció cinco distritos judiciales encabezados por jueces letrados que ya no se encargan de la jefatura política y que dejan a los jefes políticos subalternos sin juzgado. ${ }^{147}$ Los subdelegados vieron, por lo tanto, su jurisdicción contenciosa de Hacienda trastornada, ${ }^{148}$

146 AGEY, C, "Libro de decretos del primer congreso constitucional del Estado", vol. 16, f. $35,1843$.

147 Las Siete Leyes mandaron la distinción entre justicia y gobierno por medio del establecimiento de jueces de letras de primera instancia, además con sueldo, dando así más autonomía al cargo. Pero el centralismo yucateco terminó postergando una vez más la distinción. Inicialmente, por la falta de letrados, se reducen a cinco los distritos judiciales y por ende los jueces letrados, aun antes de esperar la resolución del Congreso nacional, y efectivamente ocupan los dos cargos personas distintas. Sin embargo, para enero de 1838 "se reponen los jueces legos de $1^{a}$ instancia que antes fungían en ellos” (a excepción de los cinco mencionados). AGEY, PE, CO, "Correspondencia de la Junta Departamental de Yucatán con el Gobernador del Departamento”, vol. 6, exp. 13, s/f, 1837; "Correspondencia del Prefecto del Distrito de Izamal”, vol. 7, exp. 3, s/f, 1838. 148 Este aspecto queda por estudiar. Nótese por ahora, además de la nota anterior, que bajo el centralismo no se establecieron en Yucatán los tribunales de Hacienda anunciados por las Siete Leyes. En 1841, se encargan de los "negocios de hacienda” los jueces de primera instancia. En Mérida y Campeche, el juez nombra a un empleado de la Tesorería General y de la Aduana Marítima respectivamente, para que haga de promotor fiscal. En 1843, los subdelegados de Tekax, Izamal y Valladolid son reintroducidos en dichos juicios como promotores fiscales. Mientras tanto, algunos diputados vuelven a proponer que se reúnan los tres cargos. "Ley. Reglamento de administración de justicia”, 31 de 
pero, por lo menos en la mayoría de los casos, no dejaron de ser jefes políticos. ${ }^{149}$ Por último, añadamos que la Constitución de 1841 sancionó el control del espacio gubernativo por los ciudadanos por la vía del poder judicial, al cancelar la protección a las autoridades salvo para los altos cargos.

Por otro lado, ya vimos que estas herramientas ejecutoriogubernativas son por sí mismas inefectivas y que los funcionarios dotados de ellas son más vulnerables en su manejo, justo porque poco a poco dejaron de ser también jueces, volviéndose además plenamente responsables ante la justicia. En estas condiciones, el gobierno ejecutorio reforzado condujo a la profundización de cierta práctica gubernativa tutelar: su autoridad se implementó sobre todo gracias a la práctica consensual o negociadora de la ejecución, lo que dejó espacio para el juego político o el poder de hecho. La vía expedita, pues, pudo expandirse, evitando los recursos de los gobernados, gracias a las prácticas consensuales. Y, en los hechos, incluso logró "suplantar" a la justicia.

Por ejemplo, en 1842, cuando los jefes políticos comenzaban a dejar de ser jueces, el de Valladolid actuó a modo de alcalde conciliador, y lo hizo por una vía aún más expedita que el juicio verbal. ${ }^{150}$ El caso se presentó así: la indígena Paula Chan dio unos pesos a Eligio Rosado, vecino de Valladolid, a cambio de que promoviera la liberación de su marido, encauzado por vago.

marzo 1841; AzNAr Pérez, Colección de leyes, t. II, arts. 49-51, p. 62, y AGEY, CG, $S$, "Libro de sesiones del primer Congreso constitucional del Estado", vol. 12, fs. 22, 29, 47 y 49, 1843.

149 En septiembre de 1841, por ejemplo, sólo tres dejan de ser subdelegados. Memoria, p. 7.

150 Resulta que este jefe político fue antes subdelegado-juez en el periodo republicano; renunció alegando razones de salud, de manera concomitante al levantamiento centralista de 1829. AGEY, E, "Renuncia que el c. Juan José Leal hace a sus empleos, de subdelegados de La Costa y juez de primera instancia”, vol. 2, exp. 52, 1829; J, P, “Queja de Juan José Leal, Jefe Superior Político de Valladolid contra Juan Godoy alcalde de la misma ciudad por abuso de autoridad", vol. 30, exp. 5, 1842. 
Rosado incumplió el trato y Chan le exigió la restitución del dinero. Rosado no sólo se negó a pagar sino que, al parecer, propinó unos azotes a Chan. Esta última llevó su queja al jefe político y no al juez correspondiente. Rosado, por su parte, acusó al jefe político por el modo supuestamente abusivo con el que pidió a las autoridades judiciales que impartieran justicia. Lo más significativo es que, antes de apoyar a Chan para que pudiera entablar una demanda en juicio verbal, el jefe político mandó llamar a Rosado "con el saludable objeto de conciliar amigablemente", según sus propias palabras. Expone, además, que le hizo "tomar sencilla explicación de lo que sucedía y del objeto que me había propuesto [...] corrigiéndolo a la vez por haber cintereado a la mencionada india". Ante la negativa de Rosado, el jefe político procuró "persuadirlo", inútilmente. Es decir, el jefe político presenta su actuación como una conciliación-como un procedimiento extrajudicial-. De hecho, según él la describe, su actuación se asemeja a un juicio verbal, que en todo caso hubiera tenido que realizar un alcalde, sin contar que, debido a los azotes, el asunto era en realidad de carácter penal. Todo esto lo explicó el jefe político sólo en segunda instancia, entre otras cosas porque sabía que no le correspondía llevar a cabo ningún juicio. Lo que este caso revela es que lo gubernativo era visto como más efectivo que la justicia -incluso la verbal- ${ }^{151}$ El jefe político justificó su actuación por la conciliación, lo que no sirve solamente para borrar la extralimitación en sus funciones, sino que remite al espíritu jurisdiccional de composición de intereses y legitima su procedimiento gubernativo con la imitación de las formas de un juicio verbal.

De esta manera, por medio de la imitación de sus formas, los juicios verbales que los subdelegados-jueces perdieron por la

151 En este caso, la víctima es en particular débil pues es indígena, mujer y, según el jefe político, no se dirigió al alcalde por no ser vecina. No parece que el jefe político conociera a Chan con anterioridad. 
revolución gaditana a favor de los alcaldes han sido recuperados y practicados de manera gubernativa por los jefes políticos. De paso, los jefes políticos también recuperaron la iniciativa de la composición extrajudicial. ${ }^{152}$ Lo anterior deja claro que, más que ser ejecutores de órdenes con capacidad negociadora, la negociación de intereses y derechos es justamente su función esencial. El hecho de que las formas extrajudiciales tendieran a imponerse no constituye ninguna novedad pues, además de lo comentado anteriormente, la justicia era engorrosa y costosa para la mayoría de la población desde mucho antes. Gracias a las formas extrajudiciales, el jefe político no manda de forma imperativa, sino que sigue apelando al consentimiento de los gobernados, precisamente por la debilidad del Gobierno que ya no es rey-juez y que todavía no ha ganado la autoridad ejecutiva. En resumen, los jefes políticos sirven para generar espacios de negociación dirigida, aprovechando el arma-amenaza de la ejecutoriedad, la cual, a su vez, termina siendo en muchas ocasiones el resultado de una negociación (ciertamente asimétrica).

\section{La equidad gubernativa}

Esta forma de gobierno, entonces, imita preferentemente las formas judiciales de audiencia para obtener el consentimiento de los gobernados, o en todo caso su legitimación. El ejemplo más claro es el desarrollo de las "pesquisas" e "informaciones" por parte de los jefes políticos. Éstas siguen el modelo de las sumarias que practicaban desde antes los subdelegados y de las que señalamos el formato expedito y excepcional. Es decir, que el Gobierno se legitima precisamente al patentizar que no es un poder "ejecutivo", mientras que aplica formas más que

152 Recordemos que el procedimiento de la conciliación, estrenado por la normativa gaditana, se inicia a petición de partes, mientras que, en el caso presentado, el jefe político presenta como conciliación (que ninguna de las partes pidió) un juicio verbal (informal) que él mismo emprendió. 
expeditas. Así se desarrollará lo que aquí llamamos equidad gubernativa. Recordemos que la equidad fue una forma de la justicia superior real, la más discrecional, que podía ignorar el derecho común y otras circunstancias. La desaparición de la fuente de la justicia superior, el rey, no impidió que los firmantes más humildes de las representaciones siguieran reclamando la equidad, pero ahora la piden al gobernador o al jefe político. Se trata, pues, de una equidad puramente gubernativa: es una justicia discrecional desligada de cualquier garantía superior de carácter justiciero y también de cualquier criterio públicoadministrativo. En efecto, estos procedimientos de "justicia gubernativa" no los exige ni los regula ninguna ley o reglamento. La imitación judicial es totalmente discrecional puesto que no se establece ningún control procedimental interno. De esta manera, mientras el gobierno legitima -o trata de legitimar-sus decisiones, sus procedimientos siguen siendo perfectamente discrecionales y arbitrarios. La justicia, por su parte, siendo el único recurso, no contra los actos, sino contra la responsabilidad personal de las autoridades, no enjuicia nunca los procedimientos de la vía gubernativa. ${ }^{153}$

Retomando la expresión de Luca Mannori, lo que se dio fue la "naturalización" no del derecho administrativo, como en otras latitudes, sino de la discrecionalidad gubernativa, considerada como equidad administrativa. ${ }^{154}$ Esta discrecionalidad gubernativa es arbitraria sólo si se la considera desde la perspectiva del "Estado legal" o, en el extremo opuesto, desde la perspectiva de

${ }^{153}$ Recordemos que el juicio de amparo solo podía modificar actos de las autoridades que conculcaran ciertos derechos, y sin generar jurisprudencia. 154 En EsCRICHe, Diccionario razonado de la legislación civil, de 1837, la equidad todavía es de los jueces; en la edición de 1851, concierne también a los "administradores" (Diccionario razonado de la legislación y jurisprudencia, pp. 622-623). Se asume lo que hemos llamado equidad gubernativa como administrativa en Castillo Velasco, Ensayo, t. II., pp. 262-263; al respecto, véase Brondino, "La vía gubernativa”, pp. 1026-1027. 
los ayuntamientos entendidos como órganos de autotutela, ${ }^{155}$ cuyos procederes gubernativos no son de naturaleza distinta a los de los jefes políticos. Recordemos, al respecto, la queja de la Junta Provisional Gubernativa yucateca en 1823: los ayuntamientos han generado un nuevo "despotismo", "engreídos por su representación”, mientras que los subdelegados eran "administradores" -entiéndase, como se explicita, que su "arbitrariedad" se veía limitada por su responsabilidad personal-. ${ }^{156}$ Ayuntamientos y subdelegados-jefes políticos terminarán teniendo sólo autoridad gubernativa, la de los primeros reforzada por su elección popular, la de los segundos respaldada únicamente por el nombramiento del gobernador, definitivamente electo de forma directa hasta 1862. A pesar de las denuncias contra la arbitrariedad de los jefes políticos, encabezadas por los ayuntamientos, se fue formando una cultura compartida de lo gubernativo en la que todas las instancias negociaban sus respectivas cuotas de poder y los alcances de lo que solemos llamar la "autoridad estatal". Ello llama a revisar lo que se entiende por "arbitrariedad" y "despotismo" en el contexto de la reconstrucción de la autoridad tras la independencia.

\section{CONSIDERACIONES FINALES}

Aun sin una revolución jurídica que acabara con la concepción jurisdiccional de la autoridad, la mera separación de poderes y la revolución política que barrió con el rey sí lograron modificar las formas del gobierno local. Se desarrolló lo gubernativo, no sólo como expansión de la tutela del Gobierno hacia todos los ámbitos de "lo público", sino como forma de mando,

155 Clavero, “Tutela administrativa”, pp. 419-468, y Portillo Valdés, “Jurisprudencia”, pp. 181-205.

156 BY, "Libro copiador de la correspondencia de la Junta Provisional Ejecutiva de la Provincia de Yucatán”, LMEP-110, fs. 50-51v., 1823. 
alejándose del "gobierno de la justicia" del pasado; al mismo tiempo la Justicia se mantuvo como la autoridad por excelencia y como el mecanismo fundamental de la regulación del poder. ${ }^{157}$

Con la aparición de los jefes políticos, se expandió la negociación gubernativa. Hemos tratado de mostrar la herencia del subdelegado-juez al jefe político, tanto en su faceta judicial como ejecutoria. Si, como recordamos inicialmente, la historiografía comienza a considerar la función mediadora de ambos, respecto a su estructuración, hay que asumir que la herencia del subdelegado-juez no es sólo una "arbitrariedad" irremediable, sino que la mediación negocia el consentimiento inducido de los gobernados y no la ejecución de la ley. Dicho de otro modo, como la mediación que lleva a cabo el jefe político es la que permite llegar a una decisión negociada con los gobernados, se considera equitativa y por tanto legítima. Entonces, la ley y la legalidad son objetos de negociación además de referentes de legitimación del resultado de la negociación.

Aunque los cargos de juez, subdelegado de Hacienda y jefe político tardarán todavía décadas en distinguirse (casi) cabalmente, quisiéramos subrayar que el jefe político, cuyo gobierno ejecutorio fue inicialmente endeble, cobró una relevancia que no tuvieron ni el juez ni el subdelegado de Hacienda. Hemos insistido sobre la fuerza reptante de la "justicia gubernativa" que impartió el jefe político, comparada con la impartida por el juez que, además, se volvió cada vez más "justicia de leyes" y no de jueces. ${ }^{158}$ En cuanto al subdelegado de Hacienda, una visión a mediano plazo permite considerar que la distinción de cargos se terminó dando también por cuestiones de especialización "administrativa", cuando en el último tercio del siglo "la administración" conoció un crecimiento importante. Empero, el subdelegado de Hacienda perdió relevancia de inmediato al

157 Como ya señaló Lira, “Orden público”, pp. 195-205.

158 Retomamos aquí la expresión adoptada por LoRENTE, De justicia de jueces. 
aparecer el jefe político, lo cual se expresa en el hecho de que recibía las leyes y circulares del jefe político, al igual que las demás autoridades del partido; hasta terminar como mero receptor y expedidor de fondos, bajo la autorización del jefe político.

A los procedimientos gubernativos más discrecionales, y por ende contundentes, pero cuya función era conciliadora más que ejecutora, el jefe político sumará poco a poco el nombramiento y la subordinación cada vez más exclusivos al gobernador, es decir, la función político-gubernativa que había tenido de manera puntual el subdelegado. Esto abrirá un nuevo frente para reforzar la equidad gubernativa y explica, además, que el dispositivo de la jefatura política conociera su aprovechamiento máximo -que no su invención-durante el último cuarto de siglo.

Yucatán constituye un caso específico del manejo de la cultura jurisdiccional por no haber renunciado nunca a una figura comisarial, asociada hasta 1868 a las repúblicas de indios. El caso yucateco nos ha permitido analizar y evidenciar la conformación de una concepción del gobierno que compartió todo el país, y que se caracteriza por el recurrente uso de la negociación. Las especificidades de Yucatán nos invitan, por supuesto, a emprender su comparación con otras configuraciones, en particular con las "tierras de libertad" 159 del norte y las regiones que conocieron jefes políticos de elección popular (por lo menos antes del porfiriato), con sus respectivas formas de reparto de la autoridad gubernativo-judicial y de control territorial con las autoridades municipales.

\section{SIGLAS Y REFERENCIAS}

AGN, AHH Archivo General de la Nación, Archivo Histórico de Hacien$d a$, Ciudad de México, México

AGN, I Archivo General de la Nación, Intendencias, Ciudad de México, México

159 Guerra, Le Mexique, t. 1, p. 249. 
AGN, Gs/s Archivo General de la Nación, Gobernación, sin sección, Ciudad de México, México

AGEY, C, CG Archivo General del Estado de Yucatán, Colonial, Correspondencia de los Gobernadores, Yucatán, México

AGEY, C, CA Archivo General del Estado de Yucatán, Colonial, Correspondencia de diversas autoridades, Yucatán, México

AGEY, C,J Archivo General del Estado de Yucatán, Colonial, Judicial, Yucatán, México

AGEY, CG, A Archivo General del Estado de Yucatán, Congreso, Acuerdos, Yucatán, México

AGEY, CG, C Archivo General del Estado de Yucatán, Congreso, Correspondencia, Yucatán, México

AGEY, CG, D Archivo General del Estado de Yucatán, Congreso, Dictámenes, Yucatán, México

AGEY, CG, $S$ Archivo General del Estado de Yucatán, Congreso, Sesiones, Yucatán, México

AGEY,J, $P$ Archivo General del Estado de Yucatán, Justicia, Penal, Yucatán, México

AGEY, $M, T$ Archivo General del Estado de Yucatán, Municipios, Ticul, Yucatán, México

AGEY, PE, A Archivo General del Estado de Yucatán, Poder Ejecutivo, Ayuntamientos, Yucatán, México

AGEY, PE, CO Archivo General del Estado de Yucatán, Poder Ejecutivo, Correspondencia Oficial, Yucatán, México

AGEY, PE, E Archivo General del Estado de Yucatán, Poder Ejecutivo, Empleos, Yucatán, México

AGEY, PE, G Archivo General del Estado de Yucatán, Poder Ejecutivo, Gobernación, Yucatán, México

BY Biblioteca Yucatanense, Yucatán, México

Actas del Congreso Constituyente del Estado Libre y Soberano de México, México, Imprenta Martín Rivera, 1824, t. II.

Agüero, Alejandro, "Las categorías básicas de la cultura jurisdiccional", en LORENTE (coord.), 2007, pp. 19-58.

Alcauter, José Luis, "Normas, criterios y prácticas. El papel de los subdelegados durante la vigencia de la Constitución de Cádiz", en Diego-FernánDeZ, Gutiérrez Lorenzo y Arrioja Díaz (coords.), 2014, pp. 117-138.

Alcauter, José Luis, "Subdelegados y ayuntamientos constitucionales. Momentos gaditanos en Valladolid, 1812-1814, 1820-1822”, en Soberanes y LóPEz SÁNCHEZ (coords.), 2015, pp. 1-36. 
AnCona, Eligio, Historia de Yucatán desde la época más remota hasta nuestros días, Mérida, Universidad de Yucatán, 1978 (1878-1889), t. 3.

Annino, Antonio, "Soberanías en lucha”, en Annino y Guerra (coords.), 2003, pp. 152-184.

Annino, Antonio, Luis Castro Leiva y François-Xavier Guerra (coords.), De los imperios a las naciones: Iberoamérica, Zaragoza, IberCaja, 1994.

Annino, Antonio y François-Xavier Guerra (coords.), Inventando la nación. Iberoamérica siglo XIX, México, Fondo de Cultura Económica, 2003.

Augeron, Mickaël, "Las grandes familias mexicanas a la conquista de las subdelegaciones costeras. El ejemplo del clan Peón en Yucatán (1794-1813)”, en Machuca (coord.), 2014, pp. 91-119.

Aznar Pérez, Alonso, Colección de leyes, decretos y órdenes o acuerdos de tendencia general del poder legislativo del estado libre y soberano de Yucatán, Mérida, Imprenta del Editor, 1849, 2 tomos.

BARON DE GÉRANDO, Institutes du droit administratif français ou éléments $d u$ code administratif, París, Neve-libraire de la Cour de Cassation, 1829, t. 2.

BELLINGERI, Marco, "De una constitución a otra: conflictos de jurisdicción y dispersión de poderes en Yucatán (1789-1831)", en Cuadernos de Historia Latinoamericana, 1 (1993), pp. 49-78.

Bernaldo, Pilar y Liliane Hilaire-Pérez (dirs.), Les savoirs-mondes: mobilités et circulation des savoirs depuis le Moyen Âge, Rennes, Presses Universitaires de Rennes, 2015.

Breña, Roberto (ed.), Cádiz a debate: actualidad, contexto y legado, México, El Colegio de México, 2014.

BRondino, Laura, "Les pouvoirs intermédiares et la construction de l'État mexicain. Les jefes políticos de l'état du Yucatán. 1878-1902", tesis de doctorado, París, Universidad Paris IV-Sorbonne, 2010.

BRondino, Laura, "L'implantation du système prefectoral au Mexique: quels modèles et contre-modèles pour l'administration territoriale?”, en FouRTANÉ y Guiraud (dirs.), 2011, pp. 295-307.

Brondino, Laura, "La vía gubernativa: nascita dell'autorità amminstrativa nel Messico ottocentesco?”, en Generali (coord.), 2015, pp. 1019-1027. 
Campos García, Melchor, "Que los yucatecos todos proclamen su independencia" (Historia del secesionismo en Yucatán, 1821-1849), Mérida, Ediciones de la Universidad Autónoma de Yucatán, 2013.

Campos García, Melchor (ed.), Entornos del 'ciudadanato' en Yucatán, 17501906, Mérida, Yucatán, Universidad Autónoma de Yucatán, 2006.

Campos García, Melchor y Roger Domínguez Saldívar, La Diputación Provincial en Yucatán, 1812-1823. Entre la iniciativa individual y la acción del gobierno, Mérida, Yucatán, Universidad Autónoma de Yucatán, 2007.

Campos García, Melchor, "Justicia pretoriana y reforma liberal en Yucatán (1810-1828)”, en De reribus gestis, 1 (ene.-jun. 2017), pp. 12-52.

Castillo Velasco, José María, Ensayo sobre el derecho administrativo mexicano, México, Universidad Nacional Autónoma de México, 1994, t. II.

Clavero, Bartolomé, “Tutela administrativa o diálogos con Tocqueville (a propósito de Une et indivisible de Mannoni, Sovrano tutore de Mannori y un curso mío", en Quaderni Fiorentini per la storia del pensiero giuridico moderno, 24 (1995), pp. 419-468.

Colección de Leyes, decretos y órdenes del Augusto Congreso del Estado Libre de Yucatán, Mérida, Yucatán, Imprenta de Lorenzo Seguí, 1832, 2 tomos.

Colección de los decretos y órdenes que han expedido las Cortes Generales y Extraordinarias, Cádiz, Imprenta Nacional, 1813-1823, ts. III-IV.

Delgado Aguilar, Francisco Javier, "Orígenes e instalación del sistema de jefaturas políticas en México (1786-1824)”, en Estudios de Historia Moderna y Contemporánea de México, 28 (jul.-dic. 2004), pp. 5-29.

Diario de sesiones de las Cortes Generales Extraordinarias, s. n., 1810-13.

Diario histórico de México de Carlos María Bustamante, 1822-1848, Josefina Zoraida Vázquez y Héctor Cuauhtémoc Hernández Silva (eds.), México, Centro de Investigaciones y Estudios Superiores en Antropología Social, El Colegio de México, 2001.

Diego-Fernández Sotelo, Rafael, María del Pilar Gutiérrez Lorenzo y Luis Alberto Arrioja Díaz Viruell (coords.), De reinos y subdelegaciones. Nuevos escenarios para un nuevo orden en la América borbónica, México, El Colegio de Michoacán, Universidad de Guadalajara, El Colegio Mexiquense, 2014. 
Diego-Fernández Sotelo, Rafael y María del Pilar Gutiérrez Lorenzo, "El régimen subdelegacional a la luz del orden constitucional gaditano", en Soberanes y López Sánchez (coords.), 2015, pp. 209-232.

Diego-Fernández, Rafael, Graciela Bernal Ruiz y José Luis Alcauter GuZMán (coords.), Dilemas jurisdiccionales. El entramado subdelegacional novohispano, Zamora, El Colegio de Michoacán [en prensa].

Domínguez Saldívar, Roger A., Liberalismo y municipalización. Las reformas liberales españolas en Yucatán, 1812-1822, Mérida, Yucatán, Universidad Autónoma de Yucatán, Conaculta, 2004.

Dublán, Manuel y José María Lozano, Legislación mexicana, México, Imprenta del Comercio, 1876-1912, tomos I y III.

Dzul SÁnchez, José Mauricio, “Jueces españoles y alcaldes constitucionales: la transformación de las estructuras administrativas en Yucatán, 1786-1820”, en Campos García (ed.), 2006, pp. 73-101.

El Primer Congreso Constituyente de Yucatán. Actas de Sesiones, 1823-1825, Sergio Quezada (edición, transcripción y notas), Sergio Quezada, Justo M. Flores Escalante y Emmanuel Heredia González (introducción), Mérida, Yucatán, Universidad Autónoma de Yucatán, Instituto de Historia y Museos de Yucatán, 2016.

EsCRICHE, Joaquín, Diccionario razonado de la legislación civil, penal, comercial y forense, con citas del derecho, notas y adiciones por el licenciado Juan Rodríguez de San Miguel, México, Galván, 1837.

Escriche, Joaquín, Diccionario razonado de legislación y jurisprudencia, nueva edición corregida notablemente, y aumentada con nuevos artículos, notas y adiciones sobre el derecho americano, por Don Juan B. Guim, París, Librería de Rosa, Bouret y Cía., 1851.

FALcón, Romana, El jefe político. Un dominio negociado en el mundo rural del Estado de México. 1856-1911, México, El Colegio de México, 2015.

Flores Escalante, Justo Miguel, "El primer experimento centralista en Yucatán: el proyecto de gobierno de José Segundo Carvajal (1829-1831)”, en Secuencia, 62 (mayo-ago. 2005), pp. 46-76. 
Flores Escalante, Justo Miguel, Entre el centralismo y el federalismo. Proyectos de gobierno en la peninsula de Yucatán, 1829-1839, Campeche, Gobierno del Estado de Campeche, 2010.

FourTané, Nicole y Michèle Guiraud (dirs.), Emprunts et transferts culturels: Mexique, Nancy, Presses Universitaires de Nancy, 2011.

Garriga, Carlos y Marta Lorente, Cádiz, 1812. La Constitución jurisdiccional, Madrid, Centro de Estudios Políticos y Constitucionales, 2007.

Garriga, Carlos, “Gobierno y justicia: el gobierno de la justicia”, en LorenTE, 2008, pp. 64-113.

Garriga, Carlos, "Continuidad y cambio del orden jurídico”, en Garriga (coord.), 2010, pp. 59-106.

Garriga, Carlos (coord.), Historia y Constitución. Trayectos del constitucionalismo hispano, México, Instituto de Investigaciones Históricas Dr. José María Luis Mora, 2010.

Garriga, Carlos y Andréa Slemian, “'Em Trajes brasileiros': justiça e constitução na América ibérica (c. 1750-1850)”, en Revista de História, 169 (jul.-dic. 2013), pp. 181-221.

Gayol, Víctor (coord.), Formas de gobierno en México. Poder político y actores sociales a través del tiempo, Zamora, El Colegio de Michoacán, 2012.

Generali, Dario (coord.), Le radici della razionalità critica: saperi, pratiche, teleologie. Studi offerti a Fabio Minazzi, Milán-Udine, Mimesis, Centro Internazionale Insubrico, 2015.

GüÉmez, Arturo, Mayas. Gobierno y tierras frente a la acometida liberal en Yucatán 1812-1847, Mérida, Yucatán, El Colegio de Michoacán, Universidad Autónoma de Yucatán, 2005.

Guerra, François-Xavier, Le Mexique de l'Ancien Régime à la Révolution, París, L’Harmattan, Publications de la Sorbonne, 1985.

Hespanha, Antonio M., La gracia del derecho. Economía de la cultura en la Edad Moderna, Madrid, Centro de Estudios Constitucionales, 1993. 
Hespanha, Antonio M., Introduzione alla storia del diritto europeo, Bolonia, Il Mulino, 2003 (ed. original: Panorama histórico da cultura jurídica europeia, Lisboa, Publicações Europa-América, 1999).

Hernández Ortiz, Silvana, "La política fiscal en el tránsito de la Hacienda Real a la Hacienda Pública. Imposiciones directas e ingresos comerciales en la provincia de Yucatán, 1813-1825”, tesis de licenciatura, Mérida, Yucatán, Universidad Autónoma de Yucatán, 2011.

Impugnación a las observaciones hechas por varios yucatecos al dictamen presentado a la Cámara de Senadores por sus comisiones unidas de puntos constitucionales y guerra, sobre la proposición del señor Vargas relativa a la pacificación de Yucatán, México, s. e., 1831.

Jáuregui, Luis, La Real Hacienda de Nueva España. Su administración en la época de los intendentes 1786-1821, México, Universidad Nacional Autónoma de México, 1999.

La Diputación Provincial de Yucatán. Actas de sesiones, 1813-1814, 1820-1821, introducción de Cecilia Zuleta, transcripción de Rosario Lima et al., México, Instituto de Investigaciones Dr. José María Luis Mora, 2006.

La jurisdicción contencioso-administrativa en España. Una bistoria de sus orígenes, Madrid, Consejo General del Poder Judicial, Centro de Documentación Judicial, 2008.

Las constituciones históricas de Yucatán, 1824-1905, introducción de Melchor Campos García, Mérida, Yucatán, Universidad Autónoma de Yucatán, 2009.

Lempérière, Annick, Entre Dieu et le Roi, la République. Mexico, XVIXIXème siècles, París, Les Belles Lettres, 2004.

LempérIÈRe, Annick, "La historiografía del Estado en Hispanoamérica. Algunas reflexiones”, en Palacios (coord.), 2007, pp. 45-62.

Lempérière, Annick, "Du juridique au politique. Droit administratif et réforme de l'État au Mexique dans les années 1850 et 1860”, en Bernaldo e Hilaire-PÉrez (dirs.), 2015, pp. 409-420.

LEMPÉRIÈRE, Annick, "Constitution, juridiction, codification. Le libéralisme hispano-américain au miroir du droit”, en Almanack. Guarulhos, 15 (ene.-abr. 2017), pp. 1-43. 
LiRA, Andrés, "Lo contencioso-administrativo, ejemplo difícil para el constitucionalismo mexicano", https://archivos.juridicas.unam.mx/www/bjv/ libros/6/2564/19.pdf

LiRA, Andrés, "Orden público y jurisdicción en el siglo xIx. El contenciosoadministrativo español visto desde el constitucionalismo mexicano", en Istor, 16 (2004), pp. 195-205.

LiRA, Andrés, “La facultad económico-coactiva, 1837-1899. Una aportación del régimen unitario al orden republicano en México", Estudios, 105 (verano 2013), pp. 121-133.

Lorente, Marta (coord.), De justicia de jueces a justicia de leyes: hacia la España de 1870, Madrid, Consejo General del Poder Judicial, Centro de Documentación Judicial, 2007.

LORENTE, Marta, La jurisdicción contenciosa-administrativa en España. Una historia de sus orígenes, Madrid, Consejo General del Poder Judicial, 2008.

LORENTE, Marta " "División de poderes y contenciosos de la administración: una -breve- historia comparada”, en GARRIGA (coord.), 2010, pp. 307-341.

Lorente, Marta y José María Portillo (dirs.), El momento gaditano. La Constitución en el orbe hispánico (1808-1826), Madrid, Congreso de los Diputados, 2012.

Machuca, Laura (coord.), Grupos privilegiados en la peninsula de Yucatán, siglos XVIII y XIX, México, Centro de Investigaciones y Estudios Superiores en Antropología Social, Gobierno del Estado de Yucatán, Conaculta, 2014.

MachuCA, Laura, "El cabildo de Campeche versus los subdelegados. 17911796”, en Diego-Fernández, Bernal Ruiz y Alcauter Guzmán (coords.) [en prensa].

Mannori, Luca, "Per una 'preistoria' della funzione amministrativa. Cultura giuridica e attività dei pubblici apparati nell'età del tardo diritto comune”, en Quaderni Fiorentini per la storia del pensiero giuridico moderno, 19 (1990), pp. 323-504.

ManNori, Luca, "Giustizia e amministrazione tra antico e nuovo regime”, en Romanelli (ed.), 1997, pp. 39-65. 
Mannori, Luca y Bernardo Sordi, Storia del diritto amministrativo, MilánBari, Laterza 2001.

Memoria presentada al A. Congreso del estado de Yucatán por el secretario general de gobierno en 29 y 30 de septiembre de 1841, Mérida de Yucatán, Imprenta José Dolores Espinosa, 1841.

Miño Grijalva, Manuel, Mariana Terán Fuentes, Edgar Hurtado HerNÁNDEZ y Víctor Manuel González EsPaRZa (coord.), Raíces del federalismo mexicano, México, Universidad Autónoma de Zacatecas, Secretaría de Educación y Cultura del Gobierno del Estado de Zacatecas, 2005.

Moreno, Elda, "Pueblos y ayuntamientos. La construcción de la representación política en Yucatán, 1812-1821”, en Quezada y Ortiz Yam (coords.), 2008, pp. 63-71.

Pacheco, Édgar, “Los subdelegados de la intendencia de Mérida de Yucatán. El gobierno y la Iglesia, un panorama", en Revista de la Universidad Autónoma de Yucatán, 216 (2001), pp. 59-69.

Padilla Pérez, Elvis, “Ámbitos de la justicia en Yucatán: la práctica de los procedimientos judiciales a finales del siglo xviII y primeras décadas del siglo XIX", tesis de maestría, México, Centro de Investigaciones y Estudios Superiores en Antropología Social-Peninsular, 2010.

Palacios, Guillermo (coord.), Ensayos sobre la nueva historia política en América Latina, México, El Colegio de México, 2007.

Portillo Valdés, José María, "Jurisprudencia constitucional en espacios indígenas. Despliegue municipal de Cádiz en Nueva España”, en Anuario de Historia del Derecho Español, LXXXI (2011), pp. 181-205.

QueZada, Sergio, “Federalismo y contribuciones directas en Yucatán, 18211842”, en Miño Grijalva, Terán Fuentes, Hurtado Hernández y GonZÁLEZ EsPARZA (coords.), 2005, pp. 115-123.

Quezada, Sergio, "Formas de gobierno y élites peninsulares. Federalismo y centralismo en Yucatán, 1825-1835", en Vázquez y Serrano Ortega (coords.), 2012, pp. 229-257.

Quezada, Sergio e Inés Ortiz Yam (coords.), Yucatán en la ruta del liberalismo mexicano, siglo XIX, Mérida, Yucatán, Universidad Autónoma de Yucatán, 2008. 
Quezada, Sergio, Ulrike Bock y Silvana Hernández Ortiz, Orígenes de las instituciones federales. El Poder Ejecutivo en Yucatán, 1823-1824, Mérida, Yucatán, Universidad Autónoma de Yucatán, 2012.

Real Ordenanza para el establecimiento é instrucción de Intendentes de exército y provincia en el reino de la Nueva España, México, Universidad de Guadalajara, El Colegio de Michoacán, El Colegio de Sonora, 2008.

Rojas, Beatriz, “El gobierno de los pueblos 1812-1857”, en GaYOL (coord.), 2012, pp. 381-415.

Rojas, Beatriz (coord.), Cuerpo político y pluralidad de derechos. Los privilegios de las corporaciones novohispanas, México, Centro de Investigación y Docencia Económicas, Instituto de Investigaciones Dr. José María Luis Mora, 2007.

Romanelli, Raffaele (ed.), Magistratura e potere nella storia europea, Bolonia, Il Mulino, 1997.

SiLKe, Hensel, "Mediadores del poder: la actuación de los subdelegados y su significado para el dominio español en la Nueva España, 1787-1821”, en TERÁn y GAYOL (coords.), 2010, pp. 41-63.

Soberanes, José Luis y Eduardo Alejandro López Sánchez (coords.), La Constitución de Cádiz de 1812 y su impacto en el Occidente novobispano, México, Universidad Nacional Autónoma de México, 2015.

Tau Anzoategui, Víctor, Casuismo y sistema. Introducción histórica sobre el espiritu del Derecho Indiano, Buenos Aires, Instituto de Investigaciones de Historia del Derecho, 1992.

Tau Anzontegui, Víctor, Víctor, La ley en América hispana. Del descubrimiento a la emancipación, Buenos Aires, Academia Nacional de la Historia, 1992.

Terán, Marta y Víctor Gayol (coord.), La Corona rota. Identidades y representaciones en las independencias iberoamericanas, Castelló de la Plana, Universitat Jaume I, 2010.

Vázquez, Josefina Zoraida y José Antonio Serrano Ortega (coords.), Práctica y fracaso del primer federalismo mexicano (1824-1835), México, El Colegio de México, 2012. 